


$$
\begin{aligned}
& \text { B V } \\
& 1587 \\
& .192
\end{aligned}
$$




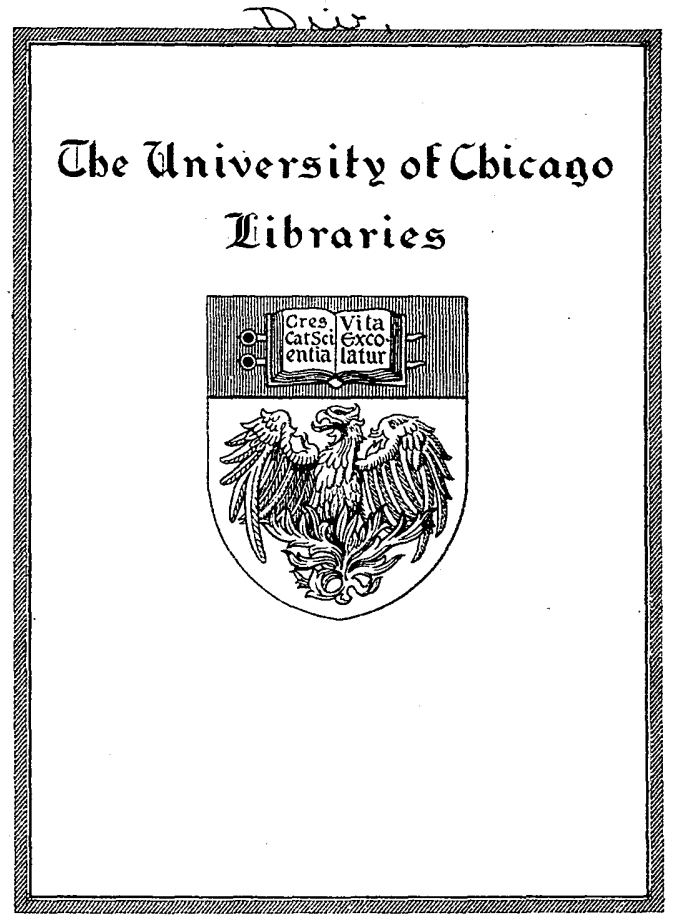




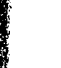

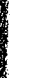

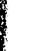

. 



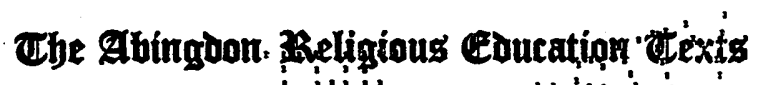

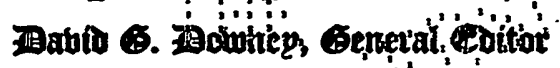

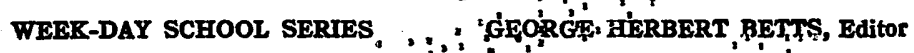

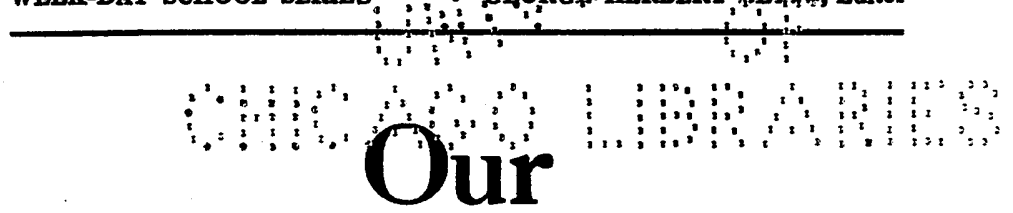

Wonderful World

\title{
Teacher's Manual
}

\author{
BY \\ JEAN GERTRUDE HUTTON
}

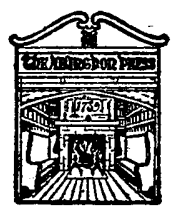

THE ABINGDON PRESS 


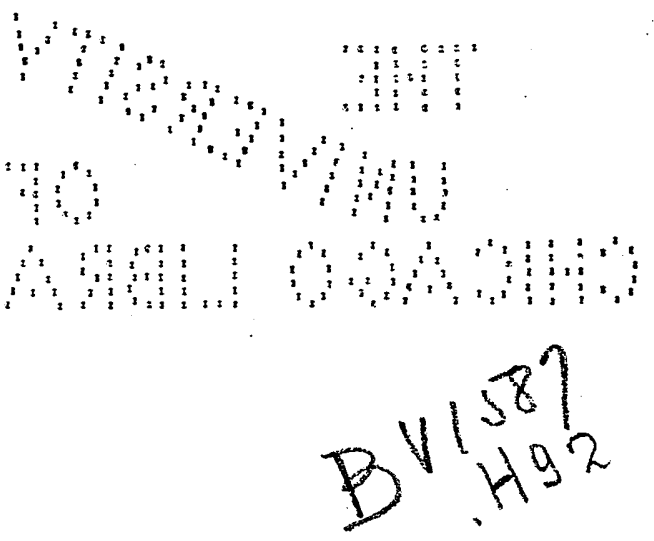

\author{
Copyright, 1927, by \\ JEAN GERTRUDE HUTTON
}

All rights reserved, including that of translation into foreign languages, including the Scandinavian 


\section{CONTENTS}

PAGE

FOREWORD................... 5

InTRODUCTION.................. 6

I. The Purpose of the Course.......... 6

II. The Teacher-His Task and QualifiCations.................... 8

III. The Child ................. I2

IV. Method in Teaching.............. I6

V. References for Further Reading and

StUdy.................... 20

\section{PART I-BACK-YARD NEIGHBORS} CHAPTER

I. Busy Plowmen................ 29

II. ANT WORKERS -I $\ldots \ldots \ldots \ldots \ldots \ldots \ldots \ldots, 33$

III. ANT WORKERS-II................ 35

IV. Spider Weavers . ................. 37

V. SpIDers and TheIr Nests........... 39

VI. The Honey Bee................ $4 \mathbf{I}$

VII. Butterflies and Moths........... 43

PART II-OUR FEATHERED FRIENDS

VIII. Hunting Birds With Eyes and Camera. 49 IX. Bird Guardians............... $5 \mathbf{5 2}$

X. Landlord to the Birds........... 54

\section{PART III-GARDEN LIFE}

XI. How Plants Grow............... 6i

XII. A Plant and Its Flowers. . . . . . . ... $6_{3}$ 
CHAPTER PAGE

XIII. Roots of MANy Forms. . . . . . . . 65

XIV. Plants and Their Stems.......... 67

XV. Green Leaf Factories . . . . . . . . . . . 68

XVI. A Field Daisy and Its Family . . . . . 70

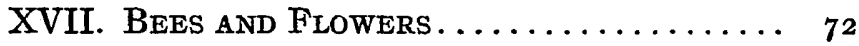

XVIII. Friendly Trees . . . . . . . . . . . 74

XIX. Fruit Trees and Forests . . . . . . 75

XX. Seed Homes.............. 77

XXI. How Seeds Find New Homes. . . . . . . 79

XXII. OUr DaIly Bread .............. 8I

PART IV-FOUR-FOOTED COMRADES

XXIII. Dog Companions............... 84

XXIV. A Faithful Servant. . . . . . . . 87

XXV. WorkING LIKE Beavers-I . . . . . . . 88

XXVI. Working LIKE Beavers-II . . . . . . . . 9I

XXVII. Sheep and Their Shepherds....... 92

PART V-THE EARTH AND ITS NEIGHBORS

XXVIII. Skyland and Cloudland . . . . . . . 95

XXIX. NeighboRS in the Sky............ 97

XXX. A Story of the Rocks. . . . . . . . . . 99

XXXI. WATER AND ICE. . . . . . . . . . . . . IO०

XXXII. Counting Up-A Review . . . . . . . . . IOI 


\section{FOREWORD}

One of the child's most natural approaches to the idea of God is through nature. To the boy or girl who has learned to see God's love and care at work in the natural world there are constant reminders of his presence.

The present volume seeks to make the child conscious of the friendly aspect of his world. It gives much interesting information about insects, birds, flowers, trees, the earth itself. It tries to connect all this in a very natural and inevitable way with the thought of God as Creator and Friend of all. It uses scientific facts, but keeps constantly in mind that the purpose of the course is to teach religion.

It is unnecessary to say to the wise teacher that the child should constantly be led beyond the textbook in his study. Pupils should have their textbooks and read the lessons. The life which they study, however, is in their gardens, beside the path, in the woods. The textbook has fulfilled its purpose when it has taught the child what to look for and how to understand the common things about him.

If through this course children shall learn to find something of the wonder and beauty in nature, and through this wonder and beauty to see the hand and heart of God at work in his world, a great contribution will be made to their spiritual growth. 


\section{INTRODUCTION}

\section{The Purpose of the Course}

OUR WONDERFUL WORLD has been planned and prepared for boys and girls in the last half of the tenth year, pupils of the fifth grade in school. If the finest results are to be obtained from the use of the lessons, it is highly essential that the teachers shall see very clearly the purpose that directed the selection of the material and the ends that should be sought in its use.

The general purpose of the course may well be viewed from a threefold approach; there are at least three factors or phases which must be considered.

First, the lessons are designed to arouse and to satisfy curiosity, to stimulate questions, and to direct the way to find answers to these questions. The lessons are intended to be suggestive and not comprehensive. Every effort has been made to verify facts according to the best authorities. Where these differ, this has been suggested, and pupils have been advised to consult varying sources, to make their own and their continued observations, and to verify by their own efforts. Many questions have been raised and purposely left unanswered, that pupils may have for themselves the joy of discovery. Few experiences in life bring greater delight than in actually finding out a new truth for oneself, and teachers are failing to do their best for pupils when this delight is taken from them. 
In addition to added knowledge of life and nature and the processes by which these go on that the child may gain from the lessons, their proper pursuit ought to give some sense of the law and order, the beauty and harmony, as well as the wisdom and the marvelous adaptation by which each part of the whole is fitted to all the rest.

Such knowledge ought to bring positive responses in a quickened love and respect for the Maker of all; in a sense of awe and reverence for the Mind that planned and produced a star or the wing of a bee, a snowflake or a volcano; a new appreciation of life in all its forms, of which the child is but one, a part of the great stream for which an increasing respect and thoughtful interest are now to be held.

Finally, out of these attitudes resulting from this increased knowledge should grow definite reactions. The child's ideas, transmuted by his feeling into ideals, are to be worked over into and out through life, and thus become his own possession. Awe, wonder, admiration, respect and love for the Creator are to show themselves in a new tenderness and consideration for the created. Life is not only to be richer and nobler, but more unified. Young as he is, the child has begun to hold a dawning idea of the one increasing purpose that runs through the ages.

The child who early comes to see God in all around him has a safeguard that nothing will break or remove. As he learns to look on all life as coming from the hand of the great Creator, and as he sees himself as a part of this vast stream, he enters into an appreciation that enriches his spirit and lifts him to a higher plane of thought and 
living. The child that in imagination watches the earth grow through long ages under the hand of the Almighty, as he prepares it to serve his great ends, experiences a stretching of mental and spiritual boundaries in a healthy and normal fashion. Imperceptibly he comes into his rightful heritage as a child of his heavenly Father.

II. The Teacher-Hrs Task and Qualifications

A most important factor in the success of any course of lessons is the teacher. A teacher of skill, insight, and sympathy may fill a poor and illplanned course so full of richness that the finest results are produced; a poor teacher may render the best course ever offered utterly barren and ineffective.

Training for teaching religion includes a thorough understanding of children, an understanding based on sound psychology, and constantly verified by observation of and association with children. It must recognize what the child is at the moment, as well as perceiving what he is to become. It must be sane and well-balanced, and entirely lacking in any unwholesome sentimentality. It must see the end to be attained in terms of developing character, and never in terms of subject-matter mastery.

Further, complete saturation with the subject matter is essential. The teacher whose knowledge is thin and cursory is sure to reveal the paucity of preparation long before the close of a single session. Pupils quickly sense the situation, and an inevitable loss of interest follows. But the greatest loss comes from narrowness of presentation. The 
teaching under such conditions must be meager; it is not likely to function in the life of the child; it is done for its own sake, and not as a part of a vital process, having interrelations with every other part.

As one aid to fullness of preparation, a reading list is given in this manual. Here again there has been no pretense at making an exhaustive list. The titles are but a few chosen from many that might have been included; and are suggestive rather than comprehensive. Some of the books are for the teacher alone, and are quite unsuited to the needs of the child of ten. Those that are marked with a $C$ may be put in the hands of the pupils themselves. Those marked $J$ have been written for children, but in many cases are too advanced for boys and girls of ten, either as to content or vocabulary, though much of the material is valuable. Encyclopedias and The Book of Knoveledge are other sources of help not given in the list.

The technical training of the teacher of which mention has been made ought to prepare a leader to select the best method of teaching, of presenting lessons, but it will not be out of place to consider method for a moment.

Changed views as to education and its great aim have brought about many changes in method, and each newcomer has been hailed as meeting all needs and overcoming most of the old difficulties. Of course many of the supposed improvements have been of less worth than was promised, but there has been a general advance.

The new emphasis on the child as the center of the learning process has demanded a change 
in approach, and some of the methods that have grown out of this have thoroughly commended themselves. Among these is the so-called "project method." Unfortunately this has been so wrapped up in technical descriptions as to become at times almost unintelligible to any but the initiate. At the same time, proving a successful method in certain grades, it has been forced upon others to which it is less fitted, and has thus become an artificial thing in many cases.

Stripped of high-sounding terms, and used sanely, the project method is seen to be the natural way of teaching, the way followed by the "born" teacher, who may indeed be quite unconscious of using any special method. To no grade in the public or the church school is the project method more suited than to the Junior Department. A consideration of the chief characteristics of the method will prove the truth of the statement.

The project method has four characteristics; for four reasons its most significant note is the wholehearted participation of the pupil. First, no one who knows a junior will fail to see at once what this means in junior teaching. The junior boy or girl learns most surely those processes in which he is permitted to engage actively. The tasks to which he is driven, more or less unwillingly, may be memorized or done perfunctorily, but inner truth does not become his actual possession until he gives himself to the learning. In part, this is the meaning of the old formula, "Impression through expression, learning through doing." As a housewife learns to make a loaf of bread only by actually making it, as one learns to drive an automobile only by driving 
one, so a child may learn to be a member of the kingdom of God only by functioning in that kingdom.

Second, purpose activity adds meaning to the method. The bread-maker may learn only through actually doing, but the doing takes on a new meaning when the product is to feed persons who are actually hungry; there will be little point and no spirit in learning to make bread as an accomplishment. No one would find much interest in learning to drive an automobile if there were no expectation of driving after the learning is accomplished. Similarly, the child is not deeply interested in learning which seems to him to have no present worth and but a doubtful future value. On the other hand, let him see that what he is gaining may have immediate use, that it has to do with the real world in which he is living at the very moment, and the whole situation is changed for him. Here again the project method fits, for an essential characteristic demands that the learning process be carried forward in a world of reality.

Third, a significant characteristic of the project method is the provision for the pupils' direction of their own activity. A former regime expected of the pupil only that type of participation that the answering of questions called for. That a pupil could pursue his own investigations, or in any degree set for himself a task was never dreamed. The teacher was an authority, handing down truth from a position that must not be questioned. There was never any sense of working toward a common goal, of feeling that the teacher was a member of a democratic group that was seeking together an end in 
which all were concerned. This is an ideal that we are slowly approaching, and one great aid to the securing of it is the project method.

Fourth, the learning process is unified when the project method is employed. Knowledge is not isolated and shut off from its natural setting. The interrelation of ideas is emphasized, not because this makes teaching easier, but because such connections exist. Learning becomes a part of life; life is learning; and every multiplication of association bonds makes retention surer, and all acquisition of knowledge simpler and more natural.

The experienced and successful teacher will say that in all of this there is little that is new; such a method has been the practice for years. This merely goes to prove that the project method is the natural way of teaching, the way that a good teacher instinctively chooses, whether the name is attached or not. It is undoubtedly true that most of the effective teaching that we have had has been done in the project spirit, even if it has not been so analyzed and called.

\section{The Child}

The peculiar suitability of the project method to the junior child may be more easily seen when viewed in the light of those characteristics that belong to the age. Therefore, further discussion of method will be deferred to later paragraphs, and we will turn to a brief study of the child in the last half of the fifth grade, the child who is living in the last half of his tenth year.

Physically, this is a time of slow growth, if we are to believe the authorities on childhood. Energy 
is being stored up for the period of rapid development that is to follow soon. Appetite is large. The child is full of energy, very active, exceedingly restless.

Mentally, the child is in a period of rapid development. Time and space are conceptions fairly well grasped by this time, and the child is striving, with a mental hunger equal to his physical hunger, to fill his mental world. The power to read rapidly enough for pleasure has been gained, and the world of books has an increasing claim on his attention. Verbal memory is good, but still calls for the concrete rather than the abstract. Observation is keen and close. There is a large interest in the physical world about him. Reasoning is not yet strong, but the child is capable of comparing, discriminating and of drawing conclusions, and he is beginning to be critical. Fact and fancy are distinguished the one from the other, and imagination is more controlled and purposeful than in the years preceding.

Curiosity is still alert, and the ten-year-old child, if his former questions have been properly treated, is still putting innumerable queries to his elders. If he has learned by sad experience that he cannot gain the help he seeks in this direction, he pursues his search in other ways, but his seeking mind will not readily give over its quest. $\mathrm{He}$ is literal; he must investigate; and he adds to his former "How?" an equally insistent "Why?"

The child of this age is quite likely to seem cruel. This arises in part from his lack of experience; he does not know how suffering actually feels. Interest in pets is increasing, and the collection craze 
runs high. The child is self-centered, rather than selfish, and moves in a world distinctly his own. Probably few adults have any idea of how strange their points of view seem to the junior at this age.

Religiously, the child of ten and a half cannot analyze or describe his experiences. He is, however, quite capable of understanding God as Father, Friend, Creator of all, Ruler and Keeper. Jesus as a man of action has a strong hold on his thinking. He needs to look upon religious life at this time as a life of activity rather than a field of belief. $\mathrm{He}$ must be helped to show his Christian principles in action, and not be expected to voice them in words. Christian teaching cannot be tied too closely to deeds. Christian standards as shown in personalities, in actual achievement, are effective and gripping.

The child of ten and a half is keenly interested in the world about him, and merely needs direction and guidance to enter into a real appreciation of nature, to feel sincere joy in its beauty, and to realize that this comes from God. The child is not irreverent in any active and deliberate fashion. $\mathrm{He}$ is often nonreverent; more often he is unconventional in his expression of feeling. The child who comes to see God in stream or sunset, in the coloring of a butterfly's wing or the make-up of a flower, experiences essentially the same sense of awe as do his elders though he may not give utterance to the emotion in the same fashion. But he may be led to show this feeling of reverence and awe through worship, and such experiences may be built into the very fiber of his being at a time when the building results in the greatest permanency. 
The junior knows no finesse; he is thoroughly genuine, and astonishingly quick to sense artificiality in others, though he may lack the power to analyze and describe it. It is important that the church-school teacher should grasp this fact and act upon it, for nowhere are children quicker to detect a forced or unnatural teaching than when it has to do with moral or religious implications. Nor is it the forced teaching alone that is rejected by the junior pupil. Every teacher has been aware at some time or other of the curious. mental imperviousness to religious teaching which the child often presents. The explanation may lie in the fact that the religious teaching has been "dragged in," or that it does not have a place in the thinking and the life of the child; or it may be the subject matter has been made to carry a conclusion that is unwarranted and illogical. In either case the result is the same. Observation and experience go to prove that the young learner closes his mind to the truth the teacher fondly hopes he is getting. Anything that hints of "preaching" or the "goodygoody" is promptly repudiated. There is no place in the junior's mind for any but the most practical and the sanest religious teaching.

A strong conviction concerning this attitude of the child mind has actuated the writing of these lessons, and only those religious implications that seem entirely natural, normal, and to be taken for granted have been retained in the text, which should be in the hands of each pupil. An effort has been made to lead the junior boy and girl, by simple and everyday paths, to see God in every manifestation of nature. Since the book is to go to 
the "average" child, more has not been attempted; the burden of the religious interpretation of the facts narrated is frankly placed on the teacher, who will know how to suit the peculiar needs of her peculiar group as no other can possibly hope to do. No skillful teacher of insight, who is concerned with the spiritual needs of her pupils, will do less. With confidence and in well-grounded faith, she will lead pupils, through Bible story and Bible poem, through picture, poetry, and nature itself, to an ever-deepening reverence and love for nature's God, to a quickened respect for his laws and a desire to obey them, and to a growing sense of the place which they and their fellows hold in the great bundle of life.]

\section{Method in Teaching}

The lessons have been planned in a more or less logical sequence to begin with the near at hand, and to proceed to less familiar topics, but there is no hard-and-fast rule that forbids a change in order if circumstances are such as to indicate the wisdom of a rearrangement. Each section has something of unity in its make-up. But any section may be interchanged with any other section to suit the season of the year in which the teaching is being carried on, or to fit other need. While reference is made in many lessons to facts given in preceding lessons, the sequence within any section may be broken without much loss, except in Part III, where each lesson depends on preceding lessons. The guiding principle, not only for the presentation of individual lessons, but also for the order in which they fall, should in every case be 
the demands that arise from the needs of the group. Not a system to be rigidly followed, but a series of stories and talks to suit the developing Christian life of pupils, is the only safe rule to follow.

In preparing and presenting the lessons, the teacher should hold four points in mind:

I. The first end of each lesson is to give information. This is not always, nor often, done with authority. Frequently questions are raised, curiosity and interest are aroused, and probable fruitful sources of investigation hinted at, in order to set the pupil to work and to instigate him to make his own discoveries and to draw his own conclusions. To be sure, mistakes are likely to occur, but gains are to be made even through mistakes, and the searching, as contrasted with the accepting attitude, is worth stimulating.

Suggestion has already been made that the information ought to be as broad as possible, and facts should be viewed from as many angles as may be used without danger of confusion. The child's desire to experience, to find out, is valuable here, and should be used to the fullest extent.

2. But knowledge, no matter how correct and worthwhile it may be, is not enough. Many of the mistakes of an older regime came from stopping with the acquisition of knowledge. Knowledge, to be of real worth, must work over into attitudes; it must have conduct-control value, if it is to be worth the trouble that it costs to acquire it. The child who learns the marvelous make-up of a bee's wing has gained a bit of knowledge that is vastly interesting; but this will be quite barren unless his attitudes toward the bee are changed through his 
new information. Wonder, reverence, humility, a new sense of kinship with all of life in some small way, a new kindness that will not ruthlessly destroy, may be reasonably expected to grow from a closer acquaintance with this and countless other facts to be gained from study.

3. Next, attitudes should work out into action, in order to make sure of their permanency and of their becoming an integral part of the very life of the child. It is not enough to know and to feel; the learner must $d_{0}$ in order to make the lesson his own in the truest sense. Since this is true, every lesson must be accompanied with

4. An activity, to be carried out in the lesson period, or to result in action a little later. It goes without saying that if the desired type of action is repeated until it becomes habitual, it becomes the natural way of responding to a situation; it is integrated with life, and is a permanent possession.

Certain activities have been offered, either in the lessons themselves, in the questions that follow, or, in a few cases, in both lesson and questions. These are thought to be such as will appeal to children of the age for which this course is prepared, to be quite simple enough to be carried out without difficulty, and yet not so easy as to lack interest. In any case they are merely suggestive, and should be discarded or modified when others more suited to the pupil are found.

In carrying out the plans all possible allowance should be made for individual differences in the pupil group. It should not be considered essential that all pupils in a group should do exactly the same type of work. This is quite in agreement 
with the spirit of the project method. As illustration, it may be said that some ten-year-old pupils delight in notebooks. Such children should be encouraged to make notebooks and make them well. To other children, notebooks are so much disliked that to prepare one would mean to destroy much of the benefit of the lessons. Again, the guiding principle is to be the need of the child; the course is not to be pursued for the sake of securing attractive books, but for making gains for and with the children. This, of course, does not mean that a teacher will laxly yield to a mere whim of a lazy or indifferent child; it is said by way of caution against the danger of trying to run every pupil into the mold of any plan, no matter how excellent the plan may be.

In the last place, it must never be forgotten that the lessons are planned for religious instruction, and not alone for interesting nature teaching. At the same time, caution should be observed to make all such religious teaching absolutely natural and direct, simple and wholesome in its approach, rather literal, rather completely shorn of symbolism and analogy, which children of this age cannot grasp. Children are getting good nature study and instruction in most public schools to-day, and are quick to detect any wresting of facts for the sake of teaching a moral truth. Not only do they detect such procedure, they resent it. Granted that pupils are too young to evaluate clever "nature-faking" at the present, the day is not far off when they will do so; and two dangers are threatened when this happens. The first is that the child will look down upon any religious teaching that resorted to such means to 
gain its end; the second is that he is in danger of throwing away the good with the bad, and repudiating all that was given him, since he found a part of it to be unworthy.

Let us make sure, then, that the religious teaching is, both in manner of presentation and in content, worthy of the Master in whose name it is offered. No class session should come to its close without a period of worship. Often this should be informal and spontaneous.

The teacher needs to evaluate most carefully the contribution which each part must make to the whole service of worship. She needs to consider what an experience of true worship is, and how it may be brought to each of the pupils. Pupil participation should be provided, according to the progressively acquired ability of the pupils to give it. Opportunities for teaching children how to pray, and how to express their hearts' desires and gratitude, will be frequent, and must be wisely used. The skillful teacher will unify the whole experience of study, activity, and worship into one beautiful whole, with no sharp transitions from one part to another. Each session is in itself a project in the finest sense, a true living together through a little section of life, a section that is natural, enjoyable, and vital; no part is exclusively religious; no part is exclusively study; no part exclusively play or work, but elements of all are to be found in each; and out of all, character development comes.

V. References For Further Reading and Study

In the following list those references marked $C$ may be given directly to the pupils to read, and 
those marked $J$, written for older pupils, may be read by the teacher:

I. Atkinson, Eleanor, Greyfriar's Bobby, Harper \& Brothers, New York, I9oI.

$J$ 2. Ball, Robert H., Starland, Ginn \& Company, New York.

$J$ 3. Baynes, E. H., Animal Heroes of the Great War, The Macmillan Company, New York, I925.

C 4. Baynes, E. H., Polaris, The Macmillan Company, New York, I922.

5. Betts, George H., How to Teach Religion, The Abingdon Press, New York, I920.

6. Betts, G. H., and Hawthorne, M. O., Method in Teaching Religion, The Abingdon Press, New York, I925.

7. Blanchan, Neltje, Bird Neighbors, Grosset \& Dunlap, New. York, I904.

8. Blanchan, Neltje, How to Attract Birds, Doubleday, Page \& Company, New York, I9I2.

9. Burroughs, John, Bird Stories, Houghton Mifflin Company, Boston, rgr2.

$J$ Io. Clarke, Eliot C., Astronomy From a Dipper, Houghton Mifflin Company, Boston, I909. II. Comstock, J. H., The Spider Book, Doubleday, Page \& Company, New York, I920. 12. Crandall, Edna, Curriculum of Worship for Juniors, The Century Co., New York, I925.

C I3. De La Ramee, Louise, "Moufflou," in Bimbi, J. B. Lippincott Company, Philadelphia, I9 то. 
$C$ I4. Ferris, Anita, The Honorable Crimson Tree, Missionary Education Movement, New York, Igr9.

$J$ I5. Grew, David, Beyond Rope and Fence, Boni and Liveright, New York, I922.

I6. Hartshorne, Hugh, Childhood and Character, The Abingdon Press, New York, I9I9.

C I7. Lankester, Sir Ray, Science From an Easy Chair, Methuen, London, I922.

18. Maeterlinck, Children's Life of the Bee, Dodd, Mead \& Company, New York, I920.

$J$ I. Martin and Haines, Firebrand, Little, Brown \& Company, Boston, rgrr.

$C$ 20. Morley, M. W., Seed Babies, Ginn \& Company, Boston, I897.

$C$ 2 r. Weed, Clarence M., Seed Travellers, Ginn \& Company, Boston, I902.

$J$ 22. Miller, Olive Thorne, First Book of Birds, Houghton Mifflin Company, Boston, I89x.

$J$ 23. Miller, Olive Thorne, Second Book of Birds, Houghton Mifflin Company, Boston, rgoI. 24. Mills, Enos, In Beaver World, Houghton Mifflin Company, Boston, I9I3.

25. Mills, Enos, The Spell of the Rockies, Houghton Mifflin Company, Boston, I9II.

26. Mills, Enos, Wonderland of the Rockies, Houghton Mifflin Company, Boston, I9I5. 27. Mills, Enos, Story of a Thousand-Year Pine, Houghton Mifflin Company, Boston, I9I4. $C$ 28. Morley, M. W., The Bee People, A. C. McClurg \& Company, Chicago, I909.

$J$ 29. McFee, Inez, Lives of Busy Neighbors, Frederick A. Stokes Company, New York, I924. 
$C$ 30. Noel, Maurice, Buz, Henry Holt \& Company, New York.

3r. Norsworthy and Whitley, Psychology of Childhood, The Macmillan Company, New York, I925.

32. Porter, Gene Stratton, Birds of the Bible, Eaton and Mains, New York, rgi6.

33. Powell, Marie Cole, Junior Method in the Church School, The Abingdon Press, New York, I923.

34. Siepert, A. F., Bird Houses Boys Can Build, Manual Arts Press, Peoria, Illinois, I9I6.

C 35. Solar, F. I., Handcraft Bird Houses, Bruce Publishing Company, Milwaukee, Wisconsin, I923.

36. Torrey, Bradford, Everyday Birds, Houghton Mifflin Company, Boston, I924.

37. Ward, Henshaw, Evolution for John Doe, Bobbs-Merrill Company, Indianapolis, I925.

C 38. White, John S., Plutarch for Boys and Girls (For the story of Alexander the Great and his horse), G. P. Putnam's Sons, New York.

$C$ 39. Wright, Julia MacNair, Sea Side and Way Side, D. C. Heath \& Co., Boston, I888 and I901. Four volumes.

40. Weed, Clarence M., Butterflies Worth Knowing, Doubleday, Page \& Company, New York, I9I7.

4I. Bergen and Caldwell. Introduction to Botany, Ginn \& Company, Boston, I9I4.

$C$ 42. Carpenter, G. C., How the World Is Fed, Ginn \& Company, New York, I907. 
$C$ 43. Crissey, Forest, The Siory of Food, Rand McNally \& Company, New York, I9r7.

44. Seers, A. Waddington, The Earth and Its Life, World Book Company, Yonkers, I922. $C$ 45. Slusser, Williams, and Benson, Luther Burbank and His Plant School, Charles Scribner's Sons, New York, I920.

\section{Magazine Articles}

National Geographic Magazine, ${ }^{1}$ Washington, D. C., Volume XXVI, I9I4,

I. "Hunting with a Lens."

2. "Explorers of a New Kind."

3. "A Book of Monsters."

4. "Monsters of Our Backyards."

Literary Digest, Funk and Wagnalls, New York, "The Science Department," for frequent references to nature subjects.

\section{Biblical References}

Genesis I. I to 2. 3 .

Job I 2. 7-IO.

Job 26. 7-I4.

Job $28 ; 37 ; 38 ; 39 ; 40 ; 4$ I.

Psalms 8, I9, 29, 65, 96, I04, I21, I47, I48.

Ezekiel 34.

Matthew I3. I-9; 24-32.

Matthew 16. I-3.

Matthew I8. I2-I4.

Luke 12.

Luke 15. I.

${ }^{1}$ Consult an index in any library for frequent articles and pictures in National Geographic Magazine bearing directly on nature themes. 
Instrumental:

\section{Hymns and Music}

"Creation," by Haydn (in part).

"Largo," by Handel.

"To a Water Lily," by MacDowell.

"To a Wild Rose," by MacDowell.

"Waltz of the Flowers," by Tschaikowski.

"To Spring," by Grieg.

"In a Garden," by Grieg.

Hymns:

"How Strong and Sweet My Father's Care!" (Anonymous.)

"The Heavens Declare Thy Glory," by Thomas R. Birks.

"The Summer Days Are Come Again," by Samuel Longfellow.

"This Is My Father's World," by Maltbie Babcock.

"Summer Suns Are Glowing," by W. W. How.

"Joyful, Joyful, We Adore Thee," by Henry van Dyke.

"Sing, for the World Rejoices," by Marianne Hearn.

"The Ships Glide in at the Harbor's Mouth," by Margaret Sangster.

"With Happy Voices Singing," by William G. Tarrant.

"Fairest Lord Jesus," by Munster.

"We Plough the Fields and Scatter," by Claudius. "The World Is Glad, the World Is Bright," by Julia Ward Howe.

"O Beautiful for Spacious Skies," by Katharine Lee Bates. 
"We Thank Thee, O Our Father" (Anonymous). "For the Beauty of the Earth," by F. S. Pierpoint.

"The Beautiful Bright Sunshine" (Anonymous).

"Day Is Dying in the West," by Mary A. Lathbury.

"There's a Wideness in God's Mercy," by F. W. Faber.

"The Lord Is My Shepherd," by J. S. Montgomery.

"There's Not a Bird With Lonely Nest," by Baptist W. Noel.

"The King of Love My, Shepherd Is," by Henry W. Baker.

\section{Poems $^{1}$}

"In the matter of poetry, a child's imagination outstrips his understanding. . . To help a child to the love of poetry is to insure for him one source of happiness in a not too happy world."

-Agnes Repplier.

*s'The Spacious Firmament on High," Joseph Addison.

*، The Child and the Piper," William Blake.

*s"The Tiger," William Blake.

*s"The Lamb," William Blake.

*"How They Brought the Good News," Robert Browning.

1 All selections designated by * are found in Poems and Rhymes, by Eva March Tappan, Houghton Mifflin Company, Boston, I907. All selections designated by $\dagger$ are found in This Singing World, an anthology compiled by Louis Undermeyer, Harcourt, Brace and Company, New York, I923.

2 Used by permission of and arrangement with Houghton Mifflin Company. 
†“Songs From Pippa Passes," Robert Browning.

* "To a Fringed Gentian," William Cullen Bryant. *"To a Waterfowl," William Cullen Bryant.

*«sThe Ivy Green," Charles Dickens.

*"The Rhodora," Ralph Waldo Emerson. *c"The Snow Storm," Ralph Waldo Emerson. *'To the Humble Bee," Ralph Waldo Emerson.

*"The Cloud," Percy Bysshe Shelley.

*"Flower in the Crannied Wall," Alfred Tennyson.

*'The Sandpiper," Celia Thaxter.

*"The Barefoot Boy," John Greenleaf Whittier. "Snowbound," John Greenleaf Whittier.

"Four Leaf Clover," Ella Higginson.

f"Who Has Seen the Wind?" C. G. Rossetti. f"Boats Sail on the Rivers," C. G. Rossetti. f"Velvet Shoes," Elinor Wylie. f"The Fog," Carl Sandburg. †"Autumn," Emily Dickinson. f"The Garden Year," Sara Coleridge. f"Do You Fear the Wind?" Hamlin Garland. f"Pedigree," Emily Dickinson. f"Daisies," Frank Dempster Sherman. f"A Caterpillar's Apology," Charles Dalmon. f"The Vainglorious Oak and the Modest Bulrush," Guy Wetmore Carryl. 


\section{†"Two Taverns," Edward Markham. †"A Prayer," Edward Markham.}

"Hurt No Living Thing," C. G. Rossetti.

"O Fair to See," C. G. Rossetti.

"Is the Moon Tired?" C. G. Rossetti.

"O Lady Moon," C. G. Rossetti.

"The Lily Has an Air," C. G. Rossetti.

"A Linnet in a Gilded Cage," C. G. Rossetti.

Many, O Jehovah my God, are thy wonderful works, which thou hast done, And thy thoughts which are to us-ward:

They cannot be reckoned up in order unto thee; If I would declare and speak of them, They are more than can be numbered.

-Psalm 40. 3-5.

"I leave to children, inclusively, but only for the term of their childhood, all and every, the flowers of the fields, and blossoms of the woods, with the right to play among them freely, according to the customs of children, warning them at the same time against thistles and thorns. And I devise to children the banks of the brooks and the golden sands beneath the waters thereof, and the odor of the willows that dip therein, and the white clouds that float high over the great trees. And I leave to children the long, long days to be merry in, in a thousand ways, and the night and the moon and the train of the milky way to wonder at."1

1 From the last will and testament of a certain man who died insane, found in $A$ Guide to Good Reading. Used by permission of and by arrangement with the publisher, Houghton Mifflin Company, Boston. 


\section{PART I}

\section{OUR BACK-YARD NEIGHBORS}

Seven lessons in OUR WONDERFUL WORLD are devoted to the common inhabitants of back yards: earthworms, ants, spiders, bees, butterflies, and moths. These lessons may be studied either at the beginning of the course, or whenever they serve most acceptably the needs of the group, or whenever they fit best into the season of the year in which the actual study of specimens is possible.

The purpose of Part $I$ is to awaken or quicken the pupils' interest in the inhabitants of their back. yards, as they discover how these small creatures live and maintain life. Lying back of this immediate end is the larger goal of helping the pupils to realize the wisdom of God's plan carried out in his creation, through which their love and respect for God may be deepened.

\section{LESSON I}

\section{BUSY PLOWMEN}

THE first lesson in a course is often the most important, and strikes the note for all the others that follow. If the children can be interested from the very first, much is gained. The teacher will be in the room and ready for the lesson well in advance of 
the arrival of pupils. Informal greetings and seating arrangements that are comfortable for pupils and that are so handled as to make for the best conditions should occupy a very brief time.

Every child should be required to have his own book, unless there is a weighty reason for an exception. The books may be given out as soon as the seating is done, and the pupils requested to turn to the page that contains the greeting to the boys and girls. This may be read aloud by the pupils, or by the leader. Try to make it seem a personal greeting from those who have prepared the book to those who are to read it. The questions will mean little at the start; they are designed to stir curiosity and thought, and to make the children eager to find the answers.

Teacher's preparation: In addition to the mastery of the lesson materials and the technic involved in presenting the lesson most effectively to the pupils, the teacher may desire to guide the pupils in a first-hand study of an earthworm.

The dissection of an earthworm in the class will be of doubtful value for children of this age, but will give the teacher a first-hand knowledge that will be valuable. Drop a large earthworm in a cup of water to which has been added a few drops of camphor. The worm will die very quickly, and should be at once removed to a soft board, and cut open from end to end with very fine scissors, the skin being pinned back on both sides with sewing needles which are easily pressed into the board. Even a low-powered microscope will show plainly the interior organs, of which a drawing should be made, for enlarged reproduction in class. The 
alimentary canal-crop, gizzard, calcareous glands and corrugated intestines-may be identified. A cross-section drawing showing by colors the alimentary canal, the nervous system and the setae, will be interesting to the pupils. Do not dissect before the class or speak of your dissection. This is for the teacher.

Procedure: Begin the discussion by raising such questions as Why do you like to travel? Have you ever thought that it would be most interesting to explore your own back yard? How many creatures actually live in your back yard? Make a list of the pupils' responses.

As soon as interest is sufficiently aroused proceed to the story contained in Lesson I, Busy Plowmen. To introduce the earthworm most effectively the leader may either read or tell the story, providing ample opportunity for questions and discussion by the pupils.

If practicable, the teacher is urged to guide the pupils through a first-hand study of earthworms. Avoid confusing technicalities, but help the pupils to see and understand the place of the earthworm in the world of nature. Let the pupils draw pictures of earthworms in their notebooks, including also a brief description of how this small creature lives and works.

At this point give the pupils an opportunity to appoint a committee to perform the experiment suggested on page 22 of the text. Emphasis should be placed on the fact that all scientists test the truth of statements for themselves, not once, but many times. Urge the pupils to make repeated and careful observations, and to write down in their notebooks exactly what they see. 
Ask the pupils to find in their Bibles and read two references: I Corinthians I. 27 and Zechariah 4. roa. Conclude the lesson with a discussion of these verses, in which the pupils may be led to see God's care and wisdom in his creation. A fine atmosphere of worship may be secured and thus crystallized in the hymn, "This Is My Father's World," stressing such lines as,

\section{"And to my listening ears, All nature sings, and round me rings} The music of the spheres."

Conclude the period with a prayer by the leader, thanking God for his wonder world, and the deeds his hand has done, with a petition for quicker senses to see and hear his message as it comes to us through the common things.

Activity: If adequate time has not been available in the class session for the pupils to complete the tasks under "Something to Do," urge them to do this at their earliest opportunity.

Ask them, in addition, to make a preliminary observation of ants, to watch their movements, their habitats, and to report any interesting observations thay may make.

Either I Corinthians I. 27 or Zechariah 4. IOa may be memorized.

\section{References:}

Encyclopadia Americana.

Sea Side and Way Side, by Julia MacNair Wright, Volume II. 


\section{LESSON II}

\section{ANT WORKERS-I}

Begin this period with worship, asking the pupils to turn first to Colossians I. I6. When they have read this verse silently, let one pupil read it aloud. Then let all join in singing "This Is My Father's World."

At this point a discussion on communion with God through the appreciation of his works in nature may be timely. Help the pupils to realize as clearly as possible the wonderful works of God as recognized in the hymn just sung. Lead the pupils in hearty participation in singing the hymn, "We Thank Thee, O Our Father." Emphasize in this hymn particularly the third stanza,

"And in the dusty city,

Where busy crowds pass by, And where the tall, dark houses

Stand up and hide the sky, And where, through lanes and alleys,

No pleasant breezes blow, E'en there, O God, our Father, Thou mak'st the flowers grow."1

Begin the actual study period by calling for a report from the committee making the earthworm experiment. Encourage them to report their observations in an interesting and intelligible manner, and guide the rest of the pupils in asking questions and sharing their own observations of earthworms. Make use of all that is offered as far as possible,

${ }^{1}$ Reprinted by permission of The Century Company. 
encouraging to better effort by commending wherever good work is shown. Move rather quickly over this part of the lesson, not permitting desultory and aimless talk to dissipate the value of the hour. Plan for a group to assemble the facts learned in the class record.

Before introducing the story in Lesson II give the pupils an opportunity to tell as many interesting things as they have observed about ants. Conclude their discussion with the reading of Proverbs 30. 24-28.

Decide, from the ability of the class, and well before coming to the session, whether the leader shall tell or read the story, or whether it shall be read by the class. Illustrate by specimens-ants, aphides, lady-bugs. Give abundant opportunity for questions. Outline the proposed experiment (page 30 in the text), and make sure the children know how to carry it out. Plan for the preparation, on the evening preceding the next session, for a reconstructed ant hill, as described in the experiment.

Activity: The assignment is suggested in the last sentence-"Find out what ants are good for!" Given properly and received with interest, this will accomplish what all good assignments are planned to do-prepare the pupils for the next lesson. Ask the pupils not to read the story this time, but to try to answer Question I under "Something to Do." Suggest that first books on science and the soils may give one answer to the question. Tell them to find out who Sir John Lubbock was, and what study he followed for a long time, and in this way they will find another set of answers. Remind them they are traveling in a new country-the ant 
country. Strange things are to be expected. Perhaps they will like to come to next session as travelers with tales of what they have found out. They may imagine they have grown very small and have taken a trip through an ant hill, and that the ants have talked and told their secrets to the visitors from Boy and Girl Land.

References: See references for Lesson $I$.

\section{LESSON III}

\section{ANT WORKERS-II}

Teacher's preparation: In order to make the present lesson as interesting and fruitful as possible, it is desirable that the teacher reconstruct an ant hill for the pupils' study during the lesson period.

Find an ant hill and drive a spade into one side of it, lifting it and thus turning over the dirt of which the hill is made. With a large spoon lift a quantity of the earth of the hill, together with the eggs, babies, queens, and workers into a widemouthed jar. Place a brick or a flat stone in the middle of a large pan of water. On this put a slab or a flat board. Pour the contents of the jar on the slab or board, and smooth it down. Cover with a sheet of glass of the same size as the board, putting a thin board over the glass to shut out the light, as ants prefer to work in the dark. Place some particles of food on the board. If the ants are left overnight, a reconstructed nest will probably be 
found in the morning, and it will be possible to observe an ant colony at work at close range. Make sure that the pan is large enough, and the water deep enough, to prevent the ants' escape.

Procedure: Probably the most interesting feature of the present lesson is the study of a reconstructed ant hill, which should be in readiness at the beginning of the session. Give the pupils every opportunity to tell what they have found out about ants since the previous session as suggested in Number I under "Something to Do."

Instead of reading the story in Lesson III, use every opportunity in the study of the ant hill to present the facts of the story informally to the pupils. Give them an opportunity to read the story later.

Guide them in making notebook drawings as suggested in Number I under "Something to Do" (page 37 in the text). Let them compare their discoveries and knowledge of ants with what Don and Ruth found out. When the pupils have exhausted their information about ants, turn the emphasis to a really more important phase of the lesson, from the conduct angle, at least-the lessons they have learned from ants.

At this point introduce Number 2 under "Something to Do." As you list on the blackboard the helpful parts of their work, help the pupils to think of and suggest many ways in which the ant is a good neighbor. Interject here Proverbs 30. 24-28, used in connection with the preceding lesson, and ask the pupils to find and read Proverbs 6. 6-8. Urge them to memorize these verses.

Conclude the period with a spontaneous worship service, including the following features: 
I. Reading by a pupil, I Corinthians I. 27, 28.

2. Hymn, "For the Beauty of the Earth," first and third stanzas.

3. Informal comments from the pupils on lessons in conduct that they have learned from ants, concluded by the reading of Proverbs 6. 6-8.

4. Prayer from the leader to summarize and clinch ideas expressed in Number 3 by the pupils.

Activity: Direct the children to look for silk weavers in their own vicinity for a day or two before they read the story; then they should go to their books for the tale of the Lady Miranda. Challenge them to answer as many of the questions following the lesson as possible.

\section{LESSON IV}

\section{SPIDER WEAVERS}

Probably no other insect is so abhorred by children as is the spider. Many children, and adults as well, fear spiders quite as much as they fear snakes. The present lesson would accomplish much if it could help the pupils to understand the ways of spiders, and to appreciate their place in the realm of nature.

Procedure: Begin the lesson with reference to two questions, Numbers 4 and 5 under "Something to Do." The pupils will doubtless be interested in these stories, and from their discussion they may proceed effectively to the story of Lady Miranda found in their text. Help them to visualize this interesting spider activity. 
Interest in Lady Miranda will be greatly stimulated if the pupils are given an opportunity to study a spider web close at hand. If possible, take the class to the garden, cellar, or attic to examine webs. Test the strength and elasticity of the web. Look for the line that runs back into the nest. Touch the web at different points, and watch the actions of the spider.

As a result of this study the pupils should be prepared to carry out the activity suggested, Numbers I and 3 under "Something to Do." Give them the necessary help to do this work successfully. Then proceed to Number 6 , in preparation for which ask the pupils to find in their Bibles James I. 4a, which seems to describe the spirit in which spiders accomplish their work.

Conclude the lesson with a brief and informal worship service in which the pupils may be led to sense a deeper reverence for God, whose hand has filled our world with so many wonderful and beautiful things.

Let the pupils sing together "We Thank Thee, O Our Father," then ask them to turn to Psalm ro4. 24, which may be read in unison. It would be well at this point to give the pupils an opportunity to explain in their own words the meaning of this verse in terms of their observations in the field of nature since they have been studying these lessons. Conclude this brief service with the hymn, "This Is My Father's World," and a prayer by the leader.

Activity: Direct the pupils to read the next story as soon as possible after the close of the session, then to look for spiders-taking good care to avoid a bite by the "black widow"! - their webs, 
nests and egg cases, that good reports for the next session may be certain.

\section{References:}

The Spider Book, by J. H. Comstock. Lives of Busy Neighbors, by Inez McFee. Sea Side and Way Side, by Julia MacNair Wright, Volume II.

\section{LESSON V}

\section{SPIDERS AND THEIR NESTS}

Teacher's preparation: To add to the interest of the class session photographs, drawings, and the decorated cards suggested in the last lesson (Number 6) may be pinned on the screen for inspection and approval. Pupils and teacher may have brought in egg cases, and this will prove an introduction to the lesson. Specimens of spiders may be brought to the class by the teacher. The usual way of preserving spiders is to place a small tuft of cotton in the bottom of a bottle to prevent the breaking of the legs, while alcohol is used as a preservative.

Procedure: Begin with a brief review of the preceding lesson, giving the pupils an opportunity to tell in a few words the new facts they have discovered in the material presented in Lesson IV and in their subsequent observations.

Proceed now to the material contained in the text, giving the pupils an opportunity to read it 
aloud, taking turns. Throughout the reading interrupt frequently with questions and explanations to make clear such points as the kinds of spider eggs, how these appear, where to look for them, and so forth. Note particularly the discussion dealing with the spider's value in the world of nature. The children will probably be interested in the suggestions made in the text concerning poisonous and nonpoisonous spiders.

To add to the interest in the tarantula, secure a skilled pianist or violinist to play several of the tarantellas. Care should be taken to see that the children sense the ignorance and superstition back of the old idea lying back of these selections; at the same time they may have some appreciation of the wild beauty of the compositions. From this lead to the calmness and trust of "How Strong and Sweet My Father's Care." Most of the pupils will know the hymn, but if they do not it will take but a few minutes to learn it. Suggest that the stanza beginning, "O keep me ever in thy love," is a beautiful prayer for protection, and may often be used.

Conclude the study with an examination of pictures and specimens provided by the teacher, as already suggested. In this connection request the pupils to carry out the suggestions made in "Something to Do," Numbers I, 2, and 3. Many pupils might also be interested in doing the task assigned in Number 4 .

The period may well end with the singing of the hymn, "How Strong and Sweet My Father's Care!" followed by references found and read in Psalm I47, verses 5 and $7 \mathrm{a}$. Close with prayer, which may later be typed and given to pupils: 
We thank thee, our heavenly Father, for the beauty of the out-of-doors; for the cooling breezes, for the freshness of water, for the glory of the sky and the strength of the hills. All things tell of thy love and care. In the lives of the little worm, the busy ant, the patient spider, we read the lessons of truth thou dost teach us. Help us that we, too, may carry out thy work as thou dost wish each of us to do. Amen.

Activity: Spend a few minutes in arranging specimens that have been brought in; in completing cards of last lesson; in entering facts in notebooks and class records; in writing letters, as suggested in assignment 4 , to distant friends, absent or prospective class members, or to parents.

Call for three volunteer groups-one to learn before the next session Psalm I9. 7-10; one to work on assignment 5, and a third to prepare assignment 6.

References: See references for Lesson IV.

\section{LESSON VI}

\section{THE HONEY BEE}

Teacher's preparation: In order that the pupils may carry out the assignments in Numbers $I$ and 2 under "Something to Do," it will be necessary for the teacher to bring bees with her to the class session. It is suggested here that he should also practice the experiments suggested in Numbers $I$ and 2 in order to aid the pupils in making worth-while 
observations. In performing the assignments in the classrooms care must be exercised not to frighten the children by bringing too many bees, for it may be that a few of the pupils will be somewhat afraid of bees.

Procedure: Begin the class session to-day with a new hymn such as "The World Is Glad, the World Is Bright," or "Joyful, Joyful, We Adore Thee." Discuss freely the meaning of the hymn, helping the pupils to understand it and to sing it with appreciation. Follow this study with a more familiar hymn to be chosen by the pupils. At this point call upon one of the pupils to read, or repeat from memory, Psalm I9. 7-Io.

Instead of giving the pupils an opportunity to read the story, "The Honey Bee," the teacher may tell it, making the life of the bee appear as dramatic as possible. When the story has been told, proceed to Number $I$ and 2 under "Something to Do." Do the work carefully and slowly so that all the process may be visible and clear to the pupils. To add to the pupils' information concerning bees, urge them to investigate the problems involved in Numbers 3 and 4 .

As suggested in "Something to Do," Numbers 5 and 6, the Bible contains many references to bees. If the pupils are interested in the task involved in Number 5 , by all means encourage them to carry it out. Ask them to look up the riddle in Judges I4 in connection with the story of Samson.

The lesson should leave the pupils full of interest in the bee, its marvelously adapted body, and its untiring industry. The study begun in this lesson should be pursued further, the teacher encouraging 
the children to come back from time to time with new observations, or with new facts gained by reading.

Activity: In preparation for the next session ask the pupils to read Lesson VII, "Butterflies and Moths," and to note especially Numbers 2, 3, 4, and 5 under "Something to Do."

\section{References:}

The Bee People, by M. W. Morley.

Lives of Busy Neighbors, by Inez McFee. $B u z$, by Maurice Noel.

Children's Life of the Bee, by Maeterlinck.

\section{LESSON VII}

\section{BUTTERFLIES AND MOTHS}

Teacher's preparation: In approaching this lesson the leader needs to consider carefully the values that may be derived from it, to the end that only the best shall be gained.

The emergence of the butterfly from the cocoon has so long been used as a symbol of resurrection that it may seem to the adult the only religious lesson to be taken from this story. The "Lesson of Faith," from Mrs, Gatty's Nature Parables, will at once come to mind, and may be used here, if this is the teaching that is chosen. It may be well to recall, however, that analogy is a dangerous tool to use in working with children. At least the caution should be uttered and the leader warned to 
make very sure that pupils are actually getting the implications that they are supposed to be getting. Death and a future life are problems that are usually not of pressing importance to the lively junior, and unless circumstances indicate the need of bringing them into prominence, another emphasis may be of greater worth.

Again, the junior is at the age when collecting has great delights for him; this instinct may be readily used here, and with little trouble pupils may be taught to collect and mount butterflies and moths. There is no doubt of the value of properly mounted and scientifically classified specimens in museums. However, pupils of ten are likely to get a better lesson through learning to admire the beauty of the living thing than can be gained through taking life for doubtful scientific gains. It is probable that it will be much wiser, and more in keeping with the spirit which the entire course of lessons is striving to foster, to have pupils study butterflies and moths from colored plates, and then to verify by observation of the living creatures, than to pursue the study by the collection method. Collections of egg cases, eggs, and cocoons are to be thought of in a different light, as these do not mean the destruction of life. It is a thrilling experience to watch a butterfly coming out of the cocoon, and getting ready for its new life; and when this has been witnessed no child is likely to forget the awe and wonder of it, or to wish to kill the lovely creature he has seen develop before his eyes. The empty cocoons are almost as valuable to the ten-year-old child as any specimen he is likely to find. Each teacher is urged to think the matter through care- 
fully, in the light of the characteristics and needs of the particular group before her, and to act for their best good.

This lesson is placed in Part $I$ as belonging naturally there, but when Lesson $I 7$, concerning the work of butterflies and moths in fertilization of flowers, is taken up, connection between the two should be made.

Procedure: Begin by asking the pupils to find, read, and memorize Ecclesiastes 3. II. Then proceed to the lesson story, giving the pupils an opportunity to read it aloud, taking turns. To add value and meaning to the narrative call for reports on Numbers 3, 4, and 5. Introduce pictures of butterflies and, if possible, actual specimens properly mounted. If it can be done, make a trip to a natural history museum, where the pupils may observe great numbers and different kinds of butterflies.

The tasks assigned in Numbers 2 and 6, given the proper guidance by the teacher, will prove interesting and valuable to the pupils.

Crepe paper may be bought at most stationery stores on which pictures of butterflies are printed in very good colors. These may be used in decorating cards to be used for Easter, for invitations or greetings; or the forms may be cut out and employed as window transparencies. Another pretty use is to mount the cut-out forms on a thin cardboard, fastening a fine wire to the body, and twisting the other end of the wire to one of the little wooden pegs used in making bouquets. The butterflies so mounted are a gay addition to a pot of flowers or ferns, and children delight in making them.

Close the class session with worship in which 
the pupils may be given an opportunity to participate in the following:

I. Singing the hymn, "For the Beauty of the Earth," first and third stanzas.

2. Reading together Ecclesiastes 3. II and Psalm I9. 7-IO.

The teacher may close the worship service with the poem, "The Caterpillar," by Robert Graves, and a prayer.

Reference: Butterflies Worth Knowing, by Clarence $\mathbf{M}$. Weed. 


\section{PART II}

\section{OUR FEATHERED FRIENDS}

PART II constitutes a project in which pupils may take keen delight. The order of lessons should be determined by the season of year at which they are being used. If it is winter, Lesson $\mathrm{X}$, "Landlord to the Birds," will make a good starting point. If shelters, feeding shelves, and food baskets are properly placed, pupils will soon make a first-hand acquaintance with their feathered tenants. Then, with one or more of the excellent bird books now so easily obtainable, children will not be long in gaining much knowledge of the birds of their vicinity, and will know for what types they may provide houses. The making of these will afford an activity that may well cover a considerable period of time.

Along with the construction of bird houses may go the consideration of the birds' contribution to man's welfare, as suggested in Lesson IX, "Our Feathered Guardians." If the section is being taken up during the summer, this lesson may be the best starting point. If the first lesson is to be given during the nesting season, Lesson VIII, "Hunting Birds with Eyes and Camera," will be the logical beginning, and the lesson may be carried on in the open, under the leadership of one who is able to show the pupils the joy of a bird hunt with a camera. It is not necessary to suggest that only those nests should be taken which 
are known to be abandoned, and in which birds are not actually living.

The study of birds ought not to stop with the few mentioned in the text. Every pupil should be encouraged to become acquainted with the birds of his own vicinity; he ought to know them by sight, by song, by nest, food habits, flight, time of coming and going. Only the most familiar have been mentioned in the text, and the leader will add many others that are of local interest.

If it is impossible to observe the actual nests of birds in their natural setting, much can be gained by visits to museums, and from the study of nature and bird books. But no matter at what time or in what place the study is being carried on, feeding places, baths and houses for birds should be provided by the pupils, both for the joy they will get from doing so, for the benefit they will derive in added appreciation, and for the very real service they may render to the community by attracting and protecting the birds.

The Milton Bradley Birds for School and Home, in four folios, containing outline patterns of forty birds, will help children to become familiar with many of the more common birds, and may be an avenue of service to children who are less favored, as the finished birds make attractive gifts for sick or shut-in boys and girls.

The purpose of the lessons in this section is in line with that of other sections. Specifically, it may be stated as the desire to create in the minds of pupils a greater tenderness and care for birds as

1Available from Milton-Bradley Company, Springfield, Massachusetts. 
a part of God's world; a deeper sense of the interdependence of all created things; and the teaching of many lessons of love and trust in God. It is to be hoped that, as the pupils cooperate to provide for the protection and welfare of birds, they may feel that they are really helping God in the care of his creatures.

\section{LESSON VIII}

\section{HUNTING BIRDS WITH EYES AND CAMERA}

Teacher's preparation: The plan for this lesson is based on the assumption that it is being used first in the section, and in the height of the nestbuilding season. Whatever topics have been under consideration in the weeks just preceding, the leader should have been encouraging the children to watch for the arrival of the birds, and to report the date and the place where each was first seen. The pupils should also be ready to welcome the little travelers with food and shelter. Birds coming north are often overtaken by a sudden late snow, and need succor. All of this will provide material for opening discussion.

It is suggested that the teacher be thoroughly prepared by a preliminary study of birds in the vicinity to lead the pupils in a fruitful study of Part II. It will be necessary, further, that the teacher make available to the pupils pictures, descriptions of birds, and any models of birds' nests or houses that will be of special interest to the pupils. ${ }^{\triangleright}$ 
Procedure: A most interesting way to begin the present lesson would be to play a simple game as suggested in Number 3 under "Something to Do." This would serve to arouse keen interest in birds and would lead into the lesson in a delightful way. Do not devote more than five minutes to this feature, and conclude with an informal discussion dealing with what the pupils already know about birds.

Pupils and leader will report on the observed activity of birds that have been seen peeping into hollows of trees, under eaves and behind shutters, in their search for nesting places. They will have been seen gathering grasses, fiber, hair, string and other building material. Their joyful songs will be most marked.

Encourage pupils to make accurate observations of nest-building, cautioning them not to alarm or disturb the birds.

With interest running high proceed to the story, "Hunting Birds with Eyes and Camera," and let the pupils read it aloud, one after another. They will delight in its interesting facts concerning their bird neighbors. A natural outgrowth of the lesson would be a bird hunt engaged in by the pupils.

It is entirely conceivable that in some situations it would be quite impossible to conduct a bird hunt out of doors. In such instances let the pupils conduct their hunt in books, magazines, or in the Bible. The book, Birds of the Bible, by Gene Stratton Porter, ${ }^{1}$ would prove valuable in a hunt for birds in the Bible.

${ }^{1}$ Published by The Abingdon Press, New York. 
If a natural history museum is accessible, the pupils would doubtless profit greatly by a visit to its bird section. In this way they could study birds less common in their own neighborhoods.

It is not enough in a bird hunt merely to look at birds. The purpose of such activities includes discovering such things as how birds build their nests. Do both birds, male and female, work at nest-building? Does the female bird work alone at nest-building? When do birds build their nests? How may one recognize a bird from the kind of nest it builds? How may one recognize a bird from its song? Many other interesting facts will be learned.

Conclude the service with a brief worship period including the following features:

I. A study of the hymn, "There's Not a Bird With Lonely Nest," which seems to have been inspired by such Scripture verses as Matthew 6 . 26 and Matthew ro. 29-3I. Help the pupils to realize the loving care of God, their Father, concerning whom it is said: "Behold the birds of heaven, that they sow not, neither do they reap, nor gather into barns; and your heavenly Father feedeth them. Are not ye of much more value than they?"

2. A prayer hymn of thanksgiving, such as, for example, "For the Beauty of the Earth," or "We Thank Thee, O Our Father," may be sung.

3. Prayer by the leader.

Activity: As an outgrowth of the lesson the pupils should make definite plans for a bird hunt, either in the out-of-doors, or in books, magazines, and the Bible, as previously suggested. In addition to making these plans, a committee should be 
chosen to write for the bird outlines, or provision may have been made for these in advance, so that the material is at hand for immediate use as suggested in Number I, "Something to Do." Discuss Number 2. What bird pictures do the children have, clipped from old picture books, magazines, or other sources? What shall be used for foundations for the sliced birds? What boxes to be used as containers? How many puzzles shall be kept for the class? Where shall the others be sent-to hospitals? mission schools? orphanages?

It is suggested that the pupils do not read Lesson IX in advance, but that they devote their time between the study of Lessons VIII and IX to carrying out plans made in connection with Lesson VIII.

\section{References:}

First Book of Birds, by Olive Thorne Miller. Second Book of Birds, by Olive Thorne Miller. Birds of the Bible, by Gene Stratton Porter. Everyday Birds, by Bradford Torrey. Bird Neighbors, by Neltje Blanchan. How to Attract Birds, by Neltje Blanchan.

\section{IESSON IX}

\section{BIRD GUARDIANS}

Procedure: No doubt the pupils will be eager to report their bird discoveries since the last class session. In this connection guide their reports by means of Number I under "Something to Do." As 
they give the names of birds that they have seen, urge them also to tell any interesting facts that they may have discovered about these birds.

It is to be hoped that many of the pupils will have searched for birds in the Bible. Give them an opportunity at this time to tell what they have discovered. Close this part of the period by calling upon a pupil to read Matthew 6. 26 and Matthew I0. 3I. Urge the class to memorize these verses. Sing the hymn, "There's Not a Bird With Lonely Nest."

Proceed next to the lesson story, "Bird Guardians," which may be read by the teacher, or by the pupils aloud, in sequence. As the pupils hear, or read for themselves, these interesting facts about birds help them to realize what birds do to be called our guardians.

As a result of this lesson on birds and their customs, the pupils will doubtless be interested in hearing "The Birds of Killingworth," by Henry W. Longfellow. Read the poem to the children in such a way as to win and hold their interest in the dramatic life of birds.

The dramatic impulse is so spontaneous, and is now so carefully fostered in the public schools, that the pupils may propose to dramatize the poem. Encourage such action, and spend some time in planning for it. Ten-year-old children are quite capable of preparing a very clever presentation, and will enjoy the making of costumes, cages, birds and other accessories for giving the play, which may be done very informally for the group, or rather more formally. as a way of sharing the pleasures of the class with parents and friends. It 
may form a part of a Bird Day Program for the class, when the work suggested in Lesson $X$, the bird books, games, pictures, and drawings may be exhibited to friends.

Activity: In connection with Lesson $\mathrm{X}$ it will be necessary for the pupils to do some rather intensive work. Ask them, first, to read the lesson story, "Landlord to the Birds," and then to begin preparations for doing the tasks assigned in Numbers 2 and 4 under "Something to Do." If it is feasible and desirable to hold a bird day, appoint a committee to begin preparations, as suggested in Number 3. Number 5 would also prove very interesting if it could be arranged. Appoint a committee to investigate and formulate plans for such an entertainment.

References: See references for Lesson VIII, also The Spell of the Rockies, by Enos Mills.

\section{LESSON X}

\section{LANDLORD TO THE BIRDS}

Teacher's preparation: To add interest and value to the lessons on birds, the pupils may plan with the teacher to have a bird day, which might include such features as the following:

I. The dramatization of "The Birds of Killingworth," by Henry W. Longfellow, as suggested in Number I under "Something to Do."

2. A display of bird pictures, nests, and houses.

3. A demonstration of bird songs and cries, as suggested in Number 5 under "Something to Do." 
At the end of the preceding lesson the teacher was asked to appoint a committee, or committees if desirable, to plan for such a demonstration of bird life. Without doubt parents and friends of the pupils would be interested in participating in such a program.

Procedure: Begin the class session with worship, using the verse, "The birds of the heaven have nests" (Luke 9. 58), as the point of departure, to be followed by the hymn, "How Strong and Sweet My Father's Care!" Call upon one of the pupils to find and read Matthew 6. 25-34. Let children speak informally of lessons God has taught us through the birds, his care of them, their service to us, their cheery ways, or other points that each may mention. Suggest petitions and reasons for thanks and lead the silent prayer of the group, closing with the hymn, "There's Not a Bird With Lonely Nest."

Proceed next to a consideration of the lesson story, which the pupils have already read in advance. It will be noted that Lesson VIII, "Hunting Birds With Eyes and Camera," and the activities presented in connection with it will be helpful and valuable in studying and discussing Lesson $X$. First of all, be sure that the pupils understand the following things:

r. What "landlord" means.

2. What birds may be found in their own neighborhood (Lesson VIII).

In the second place it will be necessary for the pupils to discover how they may attract and become acquainted with their bird neighbors. Three books will be of great value at this point: 
I. Bird Neighbors, by Neltje Blanchan.

2. How to Attract Birds, by Neltje Blanchan.

3. Any good bird book which may be found in the public library.

Help the pupils to discover for themselves ways of attracting birds, and interest them in trying some of these ways, suggested in the lesson story. It is important for them to realize the different kinds of care needed in winter and in summer and to note particularly the ways in which they may provide for the birds' protection from cats and dogs (see page I04) and the process involved in preparing baths for birds.

In the third place, a bird landlord needs to understand the various types of houses into which different birds may come. The pupils will probably enjoy studying closely this feature of the lesson in order that they may build the right kind of bird houses for their own yards. In this case, pages I05 to ro7 should be studied very carefully.

Close the class period with a brief worship period, emphasizing especially two biblical references:

I. Matthew 8. 20.

2. Matthew Io. 42 .

Let the whole class find these verses and read them silently. Then call on a pupil to read them aloud. Discuss Matthew ro. 42 especially, so that the pupils may see how acts of helpfulness to birds are in reality acts of helpfulness to God. Let the pupils choose a hymn for closing, such as "The World Is Glad, the World Is Bright," "For the Beauty of the Earth," or "This Is My Father's World."

Activity: Two things are suggested as follows: 
I. A bird day, as indicated under "Teacher's preparation," and in connection with Lesson IX.

2. Building bird houses.

Discuss freely the practical problems involved, and the procedure to be followed in building the bird houses, kinds of materials and tools to be used, expense, where the houses are to be located, and so forth. It will be a test of the ingenuity and initiative of pupils and teacher to make the most of the limited skill and whatever material is at hand, and with these to produce good shelters, feeding boxes and houses, but the returns will be great.

In the interest over the activity there is danger that the deeper religious implications may be lost to sight. Such teachings must be made most naturally or not at all. Children do not like to be "preached at," and the skillful teacher will avoid this. Nevertheless, the opportunity of showing God's care for all of his creatures, lessons of the worth of all-lessons of trust, of interdependence, of joy, of courage-may be taught so easily and wholesomely in this connection that no teacher will slight the opportunity.

\section{References:}

Bird Houses Boys Can Build, by A. F. Siepgert. Handcraft Bird Houses, by F. I. Solar. 


\section{PART III}

\section{GARDEN LIFE}

The purpose of Part III, "Garden Life," is to quicken the child's powers of observation in the world of nature; to satisfy his curiosity and deepen his wonder concerning his environment; to lead his mind to the great Creator and the marvelous wisdom that planned our beautiful world with such attention to detail; and to say with his heavenly Father, "It is good." No child should finish these lessons without a deeper reverence for God, and a keener appreciation for the law and order, the beauty and fitness, of the universe in which he is living.

At first thought it might appear that the best season of the year for the study of Part III would be the springtime. But the teacher of forethought who plans well ahead will discover that these lessons may be easily handled in the winter, provided some effort is made earlier to have the material ready. Many of the lessons should be carried on out of doors when at all possible. $A$ trip to the woods or the fields, or a city park, will make the lessons much more impressive, and will often give the teacher an opportunity to understand and to help the pupils as no other situation may.

Leaves, seed pods and stems may be gathered and preserved in the autumn. Cans or flower pots filled with earth may be planted with the proper seeds long enough before the section is to be used 
to assure the specimens that are needed for illustration. Pupils will delight in making and caring for an eggshell garden in which many small seeds may be grown for observation. Any stout pasteboard box may serve, but a small wooden box will stand the wear much better. Cut in the top of such a box a number of circles of the proper size to receive the half of an eggshell. Fill the shells with rich soil; sow the seeds, and keep them well watered and in a sunny window, and material for very interesting studies is easily obtained.

Pupils will be much interested in the making of smoke prints, an old Indian way of keeping impressions. Young children are so careless of fire that cautions should be given them, but the process is very simple.

The leader should experiment carefully first, and gain mastery of technic before attempting to show pupils how to do it. This is the procedure: Smear a sheet of clean white paper quite thoroughly, but very smoothly, with any kind of grease-lard is perhaps best. A good print will result only when the grease has been applied smoothly. Hold the greased side of the paper over a flame, passing it back and forth in or just above the flame. For classroom work, a lighted candle is most convenient; the Indians no doubt used the flame of the camp fire. Continue passing the paper through the flame till a good and even deposit of soot accumulates on the paper. Place the paper on the table, with the smoked side up. In the smoked area lay a leaf, preferably one whose veins are promient. Over this lay a sheet of plain paper, and rub the leaf well into the soot, being careful that the leaf does not 
move from its first position on the smoked area. The end of the finger or the thumb of the right hand should be used in the rubbing, while the left hand holds paper and leaf in position. Make sure that sufficient soot has adhered to the leaf to give a good print before removing it, as it cannot be put back in position, once it has been taken off. Only experimenting will tell surely how much deposit and how long rubbing is required. Next remove the paper and leaf, and place the leaf, smoked side down, on a clean sheet of paper, in the desired position, and cover with a clean sheet. Hold firmly, and rub again, till a fine impression in soot is made. This print is practically permanent, as it is rubbed off with difficulty. A set of leaves in smoke prints will form an unusual and interesting decoration for the walls of the room, or make up an interesting book on "Leaves."

Blue prints of leaves are easily made by using a photographer's printing frame, and the familiar architect's or "blue-print" paper, the only developing medium required being plenty of cold water.

In the use of specimens the teacher should be careful that children are not taught destructiveness and waste. Only so many specimens should be taken as are necessary, and pupils should be encouraged to sow seeds of wild flowers, and to protect them when they are found growing, so that others may enjoy their beauty. 


\section{LESSON XI}

\section{HOW PLANTS GROW}

A GOOD approach to the present lesson may well be made through a period of worship in which the pupils are made deeply conscious of God's workmanship in his wonder-world, and of their part in helping God in his work. Secure an atmosphere of worship and joyousness by having played on the piano, "In a Garden," by Grieg, to be followed by the hymn, "This Is My Father's World," sung by the pupils. Call upon a pupil to read Genesis I. II, I2, and let another read Matthew 6. 28-30. The hymn, "We Thank Thee, O Our Father," may then be sung. Either the teacher or one of the pupils may read "The One Thousandth Psalm," by Edward Everett Hale. ${ }^{1}$

At this point give the pupils an opportunity to express freely and spontaneously their own appreciation of the beauties of nature as they have discovered them during their studies of these lessons. Help them to realize that God is in his world providing for the needs of his people and eager for their help in completing his great creation. Gather up the pupils' expressions of appreciation in a brief prayer, and close with the hymn, "For the Beauty of the Earth."

Proceed from the worship period to the lesson story, "A Common Plant and Its Parts." The teacher may either read or tell this story, striving throughout to capture and hold the pupils' interest in the material presented. When the story has

1 Hymnal for American Youth, page 22. 
been finished discuss its different parts, and write on the blackboard the new terms, such as root, stem, threads, hairs, sessile, broth, leaves. Help the pupils to understand the meaning of these terms, and the relation of each part of the plant to every other part.

In this connection give the pupils an opportunity to do the task assigned in Number I under "Something to Do." Number 2 would prove interesting also if the teacher can make available to the pupils the necessary sources of information.

Conclude the discussion with a consideration of Numbers 5 and 6, beginning with Number 6 . In listing the plants useful to animals and man help the pupils to realize the truth of the statement contained in Genesis I. II, I2, and in Matthew 6. 28-30. Close the lesson period by reading from Browning's "Pippa Passes" the lines beginning, "All service ranks the same with God."

Activity: Interest and value may be added to the lessons on plants, if the pupils actually study and follow the growth of plants. In this connection the task suggested in Number 4 would be fruitful. An eggshell garden might be planted, as described on page 59 of this Manual.

Ask the pupils to read the lesson story found in Lesson XII, and to prepare Number I under "Something to Do" for their notebooks. Illustrations in the text, page 125 , would be helpful in performing this task.

\section{References:}

Introduction to Botany, by Berger and Caldwell. Luther Burbank and His Plant School, by Slusser, Williams, and Benson. 


\section{LESSON XII}

\section{A PLANT AND ITS FLOWERS}

Procedure: When the pupils have taken their places let the pianist play "To a Wild Rose," by MacDowell, to be followed by Luke I2. 27, read by the teacher. The hymn, "We Thank Thee, $O$ Our Father," may be used as a fitting response from the pupils. The twenty-third psalm may be repeated in unison by the pupils, followed by a prayer by the leader filled with expressions of gratitude and appreciation for God's beautiful world of nature which he has prepared for the joy and happiness of his creatures. The hymn, "Fairest Lord Jesus," may be sung to close the worship period.

Lesson XII follows naturally after Lesson XI, and the teacher may build naturally upon the emphasis made in the preceding discussion. Begin by letting the pupils read aloud the lesson story from the text, stopping frequently for discussions, questions, and explanations. Be sure that the pupils understand the meanings of the new and difficult terms found in the story: bracts, calyx, sepals, corolla, petal, stamen, pollen, flowering leaves. They might write their definitions in their note-books.

In teaching the fertilization of flowers it is much better to refrain from using the terms male and female or the father part and the mother part, as many children of ten will be confused by trying to think in this way. At the same time a good basis for future teaching may be laid by emphasizing the fact that a life substance of one sort is found in the pollen, and a life substance of another sort is 
found in the baby seed, and that only after these two substances have mingled can the new life in the seed begin to develop. More at this age is probably not required, though the teacher should aim at such an understanding of individual pupils as to have no hesitancy in giving further instruction if the time is ripe for it.

Activity: When the story has been finished proceed to the notebook work, first of all reviewing the pupils' accomplishment of the task assigned in Number I under "Something to Do." Help them to compare their work with the illustrations on page I 3 of the text.

Numbers 2, 3, and 4 will be exceedingly interesting to the average group of children. Number 2 will require investigation and Numbers 3 and 4 will result in prolonged activity frequently stimulated and checked up on by the teacher. Help the pupils to learn the different flowers of their environment. If feasible, conduct a trip to the woods or park to help the pupils increase their knowledge of flowers.

Discuss the feasibility and possibility of making a flower "beauty spot" in the neighborhood. Call attention again to the third stanza of "We Thank Thee, O Our Father" (Number 3, "Something to Do"). In this connection an eggshell garden might be planted. Help the pupils to realize the beauty of growing things and to take pleasure in watching plant life develop and change (Number 4, "Something to Do"). These assignments, if begun, should be reported on frequently.

References: For references throwing light on Lessons XII to XXI, consult references cited in connection with Lesson XI. 


\section{LESSON XIII}

\section{ROOTS OF MANY FORMS}

Teacher's preparation: The lesson story describes four different kinds of roots: those that grow in earth, water, air and in other plants. It will be well to bring specimens of these roots to class, together with a magnifying glass, in order that the pupils may have an opportunity to study them closely.

If directions for planting seeds given with Lessons XI and XII have been followed, give the pupils an opportunity to observe closely the newly found roots. Numbers 3, 4, and 5 under "Something to Do" will prove interesting to the pupils if they are worked out. Special preliminary work by the teacher for preparing and making the necessary assignments will be helpful to the students.

Procedure: Begin the lesson with a review of the two preceding lessons, making sure that the pupils understand the new and important terms found in each lesson, and that they realize the religious implications of these lessons. Ask them to find in their Bibles and read the references: Luke I2. 27 and Genesis I. II, I2.

Let individuals tell in their own words what Don and Ruth discovered about common plants and their parts and what they found out about flowers. At this point call for reports on certain investigations initiated in Lessons XI and XII, namely,

I. Lesson XI: Number 4, "Something to Do."

2. Lesson XII: Numbers 3 and 4, "Something to Do." 
Now have the pupils, one after another, read aloud the lesson story, stopping each time a new root is mentioned and described by the mother of Don and Ruth, to study first-hand specimen roots. Bring out in connection with each type of root where it thrives, how it gets its nourishment, the service it renders to the plant, the care it needs.

An interesting Bible parable may be referred to in this connection. Turn to Matthew 13. 3-7. It is doubtful whether ten-year-olds would grasp or profit greatly from the theological exposition of this parabie. Probably all that they could comprehend of this bit of Jesus' teaching would be the four kinds of soil and their effect on the depth of the root and amount of fruitfulness of the plants. These four types of plants, however, are not to be understood as being analogous to the four types of roots mentioned in the lesson.

Activity: Devote a reasonable portion of the hour to considering the assignments at the end of the lesson story, Number 2, for example. Help the pupils to think of and list in their notebooks the kinds of roots that are good for food. If feasible, carry out the task assigned in Number 3, which may be considered in the light of the biblical reference, Matthew I3. 3-7. If the pupils have planted seeds during the study of Lessons XI and XII, they ought to be able to study newly found and growing roots, as suggested in Number 4 . Number 5 is a most interesting assignment, which may be carried out with the help of the teacher.

Close the lesson period with a brief review of the lesson, the kinds of roots and their service. Ask the pupils to turn to Romans II. I6 and then read 
the verse found there. Continue with a brief service of worship, using the hymns, "For the Beauty of the Earth" and "This Is My Father's World," and a prayer by the leader.

\section{LESSON XIV}

\section{PLANTS AND THEIR STEMS}

Teacher's preparation: With the aid of the pupils gather and bring to the classroom as large an assortment of stems as possible, in order that the pupils may have an opportunity to study various kinds of stems at first hand.

Procedure: Begin the lesson with Number 4 under "Something to Do," asking the pupils to make a list of ten things that they use every day made from stems. In this way help them to see what an important contribution to life stems are. Proceed next to Number 5, asking the pupils to name the kinds of stems used for food.

With interest in stems thus aroused proceed to the lesson story, which may be read silently and then discussed by the pupils. Be sure that certain important elements in the lesson story are made perfectly clear:

I. The difference between annual, biennial, and perennial stems or plants.

2. The difference between a sirub and a tree.

3. How stems grow - up, down, and holding fast.

4. What stems are really for.

5. Lessons to be learned from stems, as in I Thessalonians 5. 2I and I Corinthians I6. I3. 
In order to become acquainted with the stems of their own environment, Numbers $I$ and 2 under "Something to Do" may be used. These lists may be written in the notebooks. Number 3 may also be considered carefully.

These assignments may be finished at home if time does not permit their being completed in the lesson period. Conclude the lesson period with a careful consideration of Number 7 , helping the pupils to realize that as there are different kinds of stems there are also different kinds of people: strong, weak, prickly, clinging, climbing. This discussion may culminate in a brief worship service in which the following hymns may be used: "Dare to Be Brave, Dare to Be Strong," and "I Would Be True." The Bible verse I Corinthians I6. I3 may be read in unison. The leader may close the class session with a brief prayer, asking God's help in developing strength and courage to meet the tasks of life.

\section{LESSON XV}

\section{GREEN LEAF FACTORIES}

Teacher's preparation: An interesting and valuable feature of the present lesson would be to make blue-print leaves. See Number I under "Something to Do." Prepare the necessary materials so as to aid the pupils in carrying out the assignment successfully.

Procedure: Ask the pupils to read silently, then aloud in unison, the Bible text, Revelation 22. 2, 
and then call upon individuals either to find and read or to repeat from memory the Bible verses used in connection with the preceding four lessons, bearing on plants, flowers, roots, and stems.

Continue with an informal worship period in which the hymns, "Fairest Lord Jesus" and "For the Beauty of the Earth," may be sung. Read or have read Job II. 7-9 and 36. 24-32. Suggest that God's greatness is shown likewise in the multitude of leaves and leaf forms, and their wonderful fitness, each to the plant to which it has been given. Close with a prayer by the leader, of thanks for the beauty of the world, and for God's care, with a petition for help to live in it with the spirit of helpfulness and the desire to serve each in his own place and to the best of his ability.

In the lesson hour, as the story is read aloud by the pupils, in turn, move slowly over the first part, since the chemical description is likely to prove difficult for the pupils to get. Ask questions, and permit questions to be asked freely, to make sure the pupils understand the facts.

In showing how all life in the animal world depends on plant life, less time will be required; the point of emphasis is that through this long chain that reaches back to the sun God is truly giving daily bread; that it is no less his gift because it does not come directly from his hand. This may seem a thought too simple to be stressed at all, but just because it is simple it has often been overlooked, and thinking of the sort that demands the immediacy of agency and denies the divinity of the more indirect way of working is at the heart of much misunderstanding and doubt. These may be 
avoided by proper teaching of basic principles at this point.

The attempt to reclothe the trees with the leaves belonging to other species is a good exercise for the imagination; but it is more: it will quicken the observation of pupils; and it ought to foster a desirable habit of inquiry that does not take facts for granted, but that looks below the surface for reasons, and that demands thinking to get at them.

Looking at leaf shapes ought also to be encouraged as a means of sharpening observation, while the making of blue prints will give a new idea of the beauty of such ordinary and familiar things as leaves, and will prove a fascinating occupation in itself. The teacher who gives a child a new interest must not forget that in doing so one more safeguard against temptation has been set up; criminals, the weak and the foolish are not recruited from the ranks of those who have wholesome and interesting matters to occupy attention.

Activity: The tasks suggested in Numbers 2 and 4 under "Something to Do" might well be carried out as a part of the class period, Number 4 being used as a service activity.

Ask the pupils to read the story found in Lesson XVI and to work on Numbers $I$ and 2 under "Something to Do."

\section{LESSON XVI}

\section{A FIELD DAISY AND ITS FAMILY}

Teacher's preparation: Specimens of daisies, dandelions, thistles, and chrysanthemums will be inter- 
esting in connection with the present lesson. To supplement the material in the text the teacher may be prepared to tell the story of Luther Burbank and the Shasta daisy (as found in the Book of Knowledge, or in a recent edition of an encyclopædia). Stories of Darwin's work with flowers may also be used.

Procedure: Begin by reference to the work of Luther Burbank with flowers, supplemented by pupils' reports on Numbers I and 2 under "Something to Do."

If the pupils have already read the lesson story there is no need to read it again. However, go over its main points and discuss these somewhat in detail in order that the pupils may understand what a composite flower is in contrast with a simple flower, and the different kinds of composite flowers. Refer now to Numbers 3 and 4 , helping the pupils to suggest and list the kinds of composite flowers to be found in their own gardens.

Strive to leave at the end an impression of the marvel of the many variations of plan to be found in the Composites, and to make the children thrill at the idea of finding out these "thoughts of God" one by one as they study patiently the works of his hands. The teacher may wish to tell them of the long and untiring effort of Darwin in his attempts to get at some of the flower secrets. Lead from this into the memory work for the day, Psalm 65. 9, and let that introduce the worship.

Ask the pianist to play "In a Garden," by Grieg, after which individual pupils may be called upon to read the following verses:

Genesis I. I Luke I2. 27. 
Isaiah 40.8.

Romans II. I6

Genesis I. II, I2.

James I. I7.

Sing together at this time the hymn, "The World Is Glad, the World Is Bright," and then lead the pupils in silent prayer, after which repeat the first stanza of the hymn, "For the Beauty of the Earth."

\section{LESSON XVII}

\section{BEES AND FLOWERS}

Procedure: Begin the lesson with Number 5 under "Something to Do." Ask the pupils to find in their Bibles and read I Peter I. 22b and Romans I2. ro. Stimulate their thinking on these verses with such questions as: How do these verses help you to remember how flowers and insects work together to help each other? Which one of these verses would make a good motto for a boy or girl to follow? Why? What kind of a school, what kind of a class, and what kind of a home would each of us have if we put these verses to the test and carried them out every day? Suggest that it is hard to remember always, and that the story of the flowers and their helpers to-day may help us to keep them in mind.

The content of the lesson story is difficult and will require careful reading and study. It is suggested that the pupils read it aloud, pausing frequently for questions, discussion, and exposition. Recall in this connection Lessons XI and XII. Help the children to get the wonder of the many plans of fertilization as found in different plants. 
Let them see the hand of God working through all these plans for the welfare of his children. Make sure the pupils catch a glimpse of the marvelous and intricate way in which the whole creation is bound together. This ought to lay the foundation for a true awe and a true reverence; it ought to foster a wholesome humility at the same time that it makes for deeper trust and dependence on God.

There is at this point, also, a grave danger into which the unwary leader may fall, in careless reference to the habits of flowers, a reference that is nearly "nature faking" at times. An example of this is seen in the frequent reference to "flowers learning to attract the insects"; as if flowers were sentient beings with the power of willing. Such teaching is very closely akin to that which John Ruskin condemned as a pathetic fallacy in his Modern Painters. To the reading of his Chapter XII in Vulume III all teachers are urged, in the hope that they, too, may come to "think strongly and see truly." The marvels of the flower world are great enough without adding to them human attributes which they do not possess.

An interesting activity will be to study and discuss the fertilization places of various flowers in the vicinity, as suggested in Numbers $I, 2,3$, and 4 under "Something to Do." Help the pupils in their study to realize the interdependence of elements in God's world.

Return at the end of the period to the Bible verses discussed earlier. Sing together a hymn, such as "The Beautiful, Bright Sunshine," first stanza, or "For All Thy Care We Bless Thee" (to be used as a prayer, to be either read aloud in unison or sung). 
Assignment: Ask the pupils to read carefully the lesson story, and to find and read the poem "Trees," by Joyce Kilmer.

Reference: Introduction to Botany, Chapter X, by Berger and Caldwell.

\section{LESSON XVIII}

\section{FRIENDLY TREES}

Procedure: Begin with a worship period designed to awaken and cultivate within the pupils an appreciation of trees. Ask the pupils to find, read silently, and then aloud in unison Psalm $x$. This may be followed by a vocalization of Joyce Kilmer's beautiful poem "Trees." If a singer is not available, the poem may be read by one of the group, or by the teacher, emphasizing particularly the last two lines:

"Poems are made by fools like me, But only God can make a tree."

Lead the pupils in a prayer of thanks to God for the beauty, the majesty, the grandeur of trees as symbols of strength and uprightness. The lesson itself may be initiated by the reading of Jotham's fable, found in Judges 9. 8-15.

If the pupils have not already read the lesson story they should be given an opportunity at this time to do so. Present the material of the lesson in the form of a great tree show, and let children choose the trees they love best for any reason- 
beauty, usefulness, or protection. Make a list of all the trees in the neighborhood, and help the pupils to suggest reasons why these trees are valuable. The material in the text will be helpful in this point.

Close the lesson period by telling the story of how a Chinese boy tried to keep Arbor Day, found in The Honorable Crimson Tree, by Anita Ferris, and published by the Missionary Education Movement.

Assignment: Ask the pupils to memorize "Trees," by Joyce Kilmer, and the Bible verses Psalm 92. I2-I4. They may read the lesson story found in Lesson XIX. The assignments under "Something to Do" in Lesson XIX are especially interesting. Urge the pupils to work especially on Numbers 2, 5, and 6 .

\section{References:}

The Honorable Crimson Tree, by Anita Ferris. Firebrands, by Martin and Haines. The Spell of the Rockies, by Enos Mills. Wonderland of the Rockies, by Enos Mills. Story of a Thousand-Year Pine, by Enos Mills.

\section{LESSON XIX}

\section{FRUIT TREES AND FORESTS}

Procedure: Lesson XVIII presented many interesting and useful facts about trees, their beauty and usefulness, and how and where certain kinds of trees grow. The present lesson emphasizes more 
especially the care of trees, and how boys and girls may render valuable service in protecting trees from harm or possible destruction.

Discuss the lesson facts, bringing out the beauty and utility of the trees. Discuss the part which pupils may play in protecting the forests: becoming intelligent through government aid, being careful of fires, watching for and destroying harmful insects, replanting, taking care of trees already growing. Help children to love and admire trees, and they will be far less likely to carelessly break and destroy them. Take them on an expedition to study the history of a tree as it is shown in the rings. An opportunity may often be found within reach. At the least, most museums of natural history give such an opportunity to the city dweller. The writing of its life history by the tree seems to be one very natural approach to a religious teaching that belongs to this lesson, and the suggestion for using it is given in the text.

Any library will help to answer the second question in the assignments. Pictures of the sequoias, the oldest living things on the earth, are quite common, and should be on hand for the study of those trees. It may be interesting to tell the pupils that most persons are greatly impressed with the vast height and circumference of these trees, and so emphasize these two points that the remarkable beauty and grace of the trees and of their foliage is often allowed to pass without comment. A second point of interest lies in the fact that these great trees bear very small cones. The life of the tree lies in its bark, and a tree that is quite hollow may still stand and grow for centuries if the bark is un- 
injured. The "burls" of the sequoia show this in a marked fashion, and if one is cut off and placed in a dish of water the feathery fronds soon begin to grow from it, and continue to keep fresh and increase in size as long as the water is kept in the container. Children in Eastern sections might be able to establish a connection with boys and girls near the sequoia forests, and arrange an exchange of burls for Eastern autumn leaves and seeds of trees.

Activity: As previously suggested, aid the pupils to establish contact with the United States Forest Service, in order that they may help preserve the trees of their own vicinity. Study carefully the illustrations in the text of how fires are started. Turn to Matthew 7. I7-20, which may be read and discussed. Close with a hymn of strength and courage, such as "True-Hearted, Whole-Hearted," and a prayer by the leader.

References: Consult references cited for Lesson XVIII.

\section{LESSON XX}

\section{SEED HOMES}

Procedure: Open the worship period with the hymn, "With Happy Voices Singing." Ask the children to read aloud the lesson text, Genesis 8 . 22, and Psalm I04. 16, 17. Genesis 8. 22 records God's promise to his children. Let us thank him for it, and let us thank him that we can learn of him through the tiny seeds as well as through the big things we meet in nature.

The lesson should emphasize the wonder of the 
tiny seed homes, and the wonderful way in which each one fits its purpose so perfectly. Have the children examine beans, and corn, and tomato plants which have been growing to be ready for this session, as suggested in Number I, "Something to Do." Let them take the tomato plants home, to be put in the garden and to watch for the sake of verifying the lesson statement. Make sure even the most literal child sees in the way the story of the corn seed is told only a bit of a fairy story in the manner of presentation. Set each child to searching for another seed story that has not been told in the session. Most of all, see that the lesson deepens the child's faith in God's tender care. Let them, in his plans for the plants and their seed, see his power and wisdom; in his care for the small things of life see a watchfulness that extends to all his creatures.

In order to get all the facts of the lesson it is suggested that the story be read aloud by the pupils. Pause frequently for discussions.

Talk over the assignments of the lesson, and when possible take the children on a field trip to discover seed homes. The highways and the hedges, the gardens and the flower beds in the country, the markets in the city have many a secret waiting to disclose itself to the eager eyes of children, if the leader but sees the chance. If the exact assignments of the lesson cannot be carried out, substitute others of equal interest, and set the youthful searchers after knowledge in the way of learning useful and interesting facts for themselves.

Assignment: Urge the pupils to read the lesson 
story for Lesson XXI and to consider carefully certain of the questions raised in "Something to Do" at the end of the lesson story, especially Numbers I, 4 , and 5 .

References: For Lessons XX, XXI, and XXII. Seed Babies, by M. W. Morley.

Seed Travelers, by Clarence M. Weed.

\section{LESSON XXI}

\section{HOW SEEDS FIND NEW HOMES}

Procedure: Begin this session with the lesson facts, bringing out by discussion what the children already know of the seed distribution, the need for it, and the way in which it is accomplished. Pupils will enjoy making cards or a booklet showing ways of seed-sowing. Sailors, fliers, tumblers, tramps, and other terms may be used as they are suggested by the children themselves, or as the method of the plant indicates. Many instances of seed distribution not given in the text should be searched for and discovered, either by reading, or preferably on a tramp through the fields and woods. Attractive decorations for the booklets or cards that contain the records of these finds may be made by an artistic arrangement of many of the seeds. Some of the "stick-tights," melon seeds, and maple keys -to note but three-may be touched with strong glue on one side, and then prettily arranged as a border for mounts, cards, or booklets.

Introduce into the discussion at this point Number 5 under "Something to Do." Emphasize espe- 
cially definite things that the pupils may do to help preserve the wild flowers in their vicinity. Number 3 is also interesting. Help the pupils to find in their Bibles the parable of the sower, and also the parable of the tares and the wheat. At this point introduce Number 7. Suggest that each one undertake to carry out the seventh assignment, and that it may be a "secret assignment" to be shown only to the one each child loves the bestperhaps this will be mother, or some friend or a teacher. Emphasize, with caution, that each is to look for the faults in his own garden, the "thistle seeds" that must not be allowed to grow; but that we will remember what Jesus said about judging, and will not judge others. Jesus also taught the same truth by telling of a man who tried to pull a tiny mote out of another's eye when there was a big beam in his own eye! So we will look for the good seeds in the deeds of our friends, and that will be one way of sowing them, for good deeds are easy to copy.

From this point proceed to the worship period, using the following:

r. Hymn, "O Beautiful for Spacious Skies," first stanza.

2. Reading by a pupil, Genesis I. Ir, I2.

3. Hymn, "How Strong and Sweet Our Father's Care!"

4. Hymn, "O Jesus, Prince of Life and Truth," first and third stanzas; or "Fairest Lord Jesus."

5. Closing prayer by the teacher expressing thanks and appreciation to God for his provision for his children everywhere. 


\section{LESSON XXII}

\section{OUR DAILY BREAD}

Teacher's preparation: Bread is such a commonplace element in the daily life of American boys and girls that they probably seldom think of where it comes from, how it is made, or of the facts that there are vast numbers of boys and girls and men and women in some sections of the world who often go hungry for the lack of bread.

It is highly desirable in the course of the present lesson for the pupils to realize that bread is something for which they should be exceedingly thankful, and something that they should gladly share with their less fortunate fellows.

To make the lesson effective prepare in advance for Number 2, "Something to Do," to be carried out in the class, and see to it that in accordance with Number 3 many pictures of wheat fields, reapers, flour mills, bakeries, and bread are in evidence in the room.

Procedure: Begin the lesson period with Number 2, giving the pupils an opportunity to indicate on an enlarged map of the world those sections from which their food comes. Children will delight in displaying thus their knowledge of their world and its resources. Help them in this connection to realize the vastness of God's provision for their every need.

Now introduce the lesson story, which may be told or read by the teacher. When you have finished, call the pupils' attention to the pictures which you have provided. Help them to under- 
stand all that is involved in supplying them with one loaf of bread. At this point the verse, "Back of the loaf, the snowy wheat," may be introduced.

Jesus often referred to bread in his teaching. In John 6. 2-I3 may be found a very interesting story of how Jesus taught a large crowd of people to share bread. This story may be told briefly to the pupils.

Concerning himself Jesus once said, "I am the bread of life." In the prayer which Jesus taught his discriples he included the phrase, "Give us this day our daily bread." It is said that Jesus prayed that prayer because large numbers of people in his country actually suffered extreme physical hunger.

As an outgrowth of this lesson help the pupils not only to be grateful for the bread they eat but also to be definitely led to share their bread with others less fortunate. Introduce facts concerning famine conditions in the Near East and in certain other sections of the world ravaged by war and pestilence. Close the session with a worship period including the hymn, "We Plough the Fields and Scatter," the first stanza, Bible references, such as Psalm 8I. $x 6$ and Psalm I03. I-5 and the Lord's Prayer, to be recited in unison. The hymn, "O Beautiful for Spacious Skies," may also be sung, especially the first stanza. 


\section{PART IV}

\section{FOUR-FOOTED COMRADES}

TmIs section, dealing with the four-footed friends of man, stands quite independently of the other sections of the course, and hence may be introduced at any convenient time. Three of the animals studied-the dog, the sheep, and the horseare more or less well known to every child. The fourth, the beaver, very probably has never been seen by any of the group, unless a stuffed specimen in some museum forms an exception. Yet the ways of this creature, and the important part it played in the early history of this country, make it such an interesting friend that there will be no difficulty in gaining the pupils' interest.

In arranging to use the various sections of the course care and foresight should be used so that a natural approach is rendered certain. For example, in rural schools, sheep-shearing time may turn the attention of the pupils to the debt man owes this woolly friend, and the lesson on sheep might quite logically be followed by other fourfooted friends of which the children may wish to know more. In other sections, agricultural fairs may bring the thought of both sheep and horses to the fore. Study in the public-school classes of the change of seasons may bring the cold of the extreme north to mind, recall the service of the dogs in the Nome epidemic, and suggest a most natural and interesting beginning. The coming of 
the cold in the winter may call attention to the need for warm clothing, and so set forth our debt to the sheep. A. few months ago all the children in an entire valley were nearly beside themselves with delight over the clever performances of a troupe of trained ponies and an equally clever troupe of trained dogs, and there would have been not the slightest difficulty in holding their attention and keen interest in any study that would have given more knowledge of dog or horse! Perhaps a child's own pony, a pet dog, or a summer-vacation experience on the farm will offer the best starting point. So long as it is not forced and artificial, the exact point of contact does not matter.

In general, the purpose of the lessons in this section is the same - to make the pupils more aware of man's debt to these coworkers who have ministered so often and so faithfully to his needs, to lead children to be kinder and more considerate of all animal pets, to help boys and girls to understand how man's welfare is often more closely related to the welfare of the animal world than is generally noted, to arouse a sense of "fair play" toward animals, and to deepen respect for all of God's creatures, even though many of them are but "dumb animals."

\section{LESSON XXIII}

\section{DOG COMPANIONS}

Teacher's preparation: The present lesson ought to find a point of contact in the pupils' interest, 
for what boy or girl has not cherished or at least longed for a pet? The lesson story is full of interesting details of dog life, which may be supplemented by the story of Stickeen, by John Muir, and $A t$ the Gate, by Terhune.

In planning the lesson activities strive to make a practical appeal to the pupils' love and care of pets, as suggested in Number 4 under "Something to Do." As an added attraction the pupils might be interested in having a dog show, or a pet show, to which they would bring their pets. This feature could be held on an afternoon after school, and could be stimulated by means of posters and advertisements made by the pupils.

Procedure: Begin with an informal worship service introduced by the hymn, "Summer Suns Are Glowing." Ask the pupils to find in their Bibles and read silently Isaiah II. 6-9, a beautiful word picture of what the world would be like if all hate could be banished, and only love be permitted to rule. Call upon one of the pupils to read the paragraph aloud. Then discuss it freely. The hymn, "There's Not a Bird With Lonely Nest," may be sung, followed by a prayer, in which the teacher may lead the pupils in expressions of gratitude for their pets and in petitions for guidance in taking the best care of their pets.

Let the pupils read the lesson story aloud, in sequence. Pause frequently for questions and discussion, giving the pupils ample opportunity to discuss their interest in and experiences with dogs. The lesson material may be supplemented by the use of material suggested in Numbers $I, 3$, and 5 under "Something to Do." 
As an outgrowth of the material presented in the lesson, guide the pupils in thinking of ways in which dogs help humans. For this the pupils will likely want to discuss various types of dogs and the qualities for which they are known, such as the Saint Bernard, the bloodhound, the poodle, the collie, and just the commonplace mongrel. Keep this part of the period alive and vital with interest.

It may be that there may be at least a few in the class who are afraid of dogs. This would be a fine opportunity to help the pupils analyze, rationalize, and begin to overcome their fear of dogs. Help them to discover ways of establishing friendship with dogs.

Activity: Turn to a discussion of how a boy or girl may take the proper care of dogs. Discuss the kinds of care of which dogs stand in need, and specific things which the pupils may do to provide that care. At this point Number 4 under "Something to Do" may be introduced. Discuss in detail ways of providing drinking fountains for dogs, and appoint a committee to carry out the plans made by the class.

\section{References:}

Greyfriars Bobby, by Eleanor Atkinson. Animal Heroes of the Great War, by E. H. Baynes. "Moufflou," in Bimbi, by De La Ramee. National Geographic Magazine, March, I9I9. 


\section{LESSON XXIV}

\section{A FAITHFUL SERVANT}

Procedure: This lesson should be taught with many pictures at hand for illustration. One number of the National Geographic Magazine is devoted to the horse, and will give much information. Mounted pictures to be passed and studied will be valuable, such as Rosa Bonheur's "Horse Fair," pictures cut from magazines and newspapers, of famous racing horses, or such pictures as may be found in illustrated copies of Black Beauty.

Discussion as to the types of horses and the special uses of each type may be carried to whatever extent the leader deems wise; this will vary greatly with the locality of the class. Only one instance of special adaptation to climate is given, that of the Iceland pony, but such illustrations may be multiplied if the teacher desires to do so. In talking of the service of the horse to man in the field of medicine it may be interesting to have a doctor or a nurse who knows how to talk to children in the right way tell how the toxin is made and how surgeons use horse hair. If preferred, the pupils may find out these facts by reading in the Book of Knowledge or in the encyclopedia.

Let the pupils read the lesson story aloud in the class. Give ample opportunity for free discussion of points raised in the lesson story. The material in the text may be supplemented by the poems, "Sheridan's Ride" and "How We Brought the Good News." Let the pupils discuss freely the service rendered by the horses described in these 
poems. Now turn to Job 39. I9-25 and read the description of a horse found there.

Discuss in conclusion the service of the Society for the Prevention of Cruelty to Animals. If there is a local organization, discover ways of cooperating with its program for the care and protection of dumb animals. Close with a prayer of thanks to God for animal friends of strength, beauty, and fidelity.

Activity: Wherever possible, take the children at the close of the session to a museum where they may see the arrangement of fossils that shows the evolution of the horse. If this is not possible, see that the plates in encyclopædias or natural histories are in readiness for their study, with the leader at hand to explain the development.

\section{References:}

Animal Heroes of the Great War, by E. $\mathbf{H}$. Baynes.

National Geographic Magazine, November, I9ı6.

\section{LESSON XXV}

\section{WORKING LIKE BEAVERS-I}

Teacher's preparation: Lessons XXV and XXVI are devoted to a study of beavers. It would be well for the teacher to become thoroughly familiar not only with the contents of each lesson story, but also with other material throwing light on beavers, such as Bulletin 1078, United States De- 
partment of Agriculture, and In Beaver World, by Enos Mills.

Procedure: Begin the session with singing, using "The Beautiful, Bright Sunshine," or "We Thank Thee, O Our Father." Let pupils have in their hands typed verses chosen from Psalm ro4, using I0, IIa, I2, I4, I8, 20, 22, 24. Call for the reading of them in order, and comment on the selections taken from a poem written long ago by one who was studying, as we are, Jehovah's care over all his works.

Introduce then the story of the beaver, an animal so shy that there are still many things about its ways of living that we do not know surely. Some child is almost sure to bring up many things once believed about beavers, but now questioned or entirely discredited, such as using the tail as a trowel. Tell them that few persons have ever been able to get close enough to the beavers to be quite sure what they do. There is little doubt that the tail is used to give warning, and as a balance when standing. It may be well to suggest that persons who have inspected the beaver homes may have seen the marks of the tails on the mud and thus have supposed that the beavers must have used the tail as a plasterer uses a trowel. Insist that the true scientist does not jump at conclusions, but withholds his judgment until all facts are in hand. To lay the foundation of such an attitude in the practice of the pupils is in itself well worth while, and the attempt to do so should receive much attention on the part of the leader.

It is suggested that this period may well be devoted to a rather intensive study of beavers, including the following features: 
I. The lesson story told by the teacher.

2. The beavers' help in making land.

3. The fur trade of colonial days and its effect on American history.

4. The protection and care of beavers.

5. How beavers build their homes.

6. Numbers I and 2 under "Something to Do."

Assign specific topics dealing with these major subjects to individual pupils and then devote the following lesson hour to reports on these topics. Have on hand and easily available for the pupils such references as the following:

I. Bulletin 1078, United States Department of Agriculture.

2. In Beaver World, by Enos Mills.

3. Copies of the National Geographic Magazine, and Nature Magazine, containing articles on beavers (consult library files).

\section{Longfellow's "Hiawatha."}

Guide the pupils in their study, so that they may be able to make interesting and thorough reports on their problem.

At the close of the period conduct a discussion bearing on Number 6, helping the pupils to think of lessons to be learned from beavers. These suggestions may be written on the blackboard and in notebooks, to which the Bible verse may be added, "Whatsoever ye do, work heartily" (Colossians 3. 23 ).

Conclude with the hymn, "Dare to Be Brave, Dare to Be True," and with a prayer by the leader, in which the pupils may be led to realize their responsibility as workers in God's world.

References: For Lessons XXV and XXVI. 
In Beaver World, by Enos Mills.

The Spell of the Rockies, by Enos Mills.

Wonderland of the Rockies, by Enos Mills.

National Geographic Magazine, November, I9ı6.

\section{LESSON XXVI}

\section{WORKING LIKE BEAVERS-II}

Procedure: The present lesson should build upon the one preceding. Begin by asking the pupils to think of and mention the lessons learned from beavers (Number 6). These may be crystallized in the verse, Colossians 3. 23.

When the lesson story has been told by the teacher proceed to the pupils' reports on questions which they studied during the preceding session. These reports will bear specifically on the following topics:

I. Study topics Numbers I and 2 under "Something to Do," Lesson XXV.

2. The beavers' help in making land.

3. How beavers build their homes.

4. The protection and farming of beavers.

5. The fur trade of colonial days and its effect on American history.

After these reports have been made and have been discussed freely by the pupils, turn to a consideration of Number 5 under "Something to Do." Help the pupils to think of the things they like best about beavers. Compare these responses to the results gained in considering Number 6 under "Something to Do" in Lesson XXV. Now intro- 
duce two more verses from the Bible that throw light on lessons learned from beavers, Ecclesiastes 9. Io and Romans I4. 7. Ask the pupils to memorize these verses. Sing together in closing any two fitting hymns chosen by the pupils and conclude with a brief worship period of prayer that we may have the help of the heavenly Father in all that we do, so that we do not forget how far reaching our deeds may be in their influence on the lives of others, and that, like the beaver, we may go about our tasks without haste and with a willing spirit.

\section{LESSON XXVII}

\section{SHEEP AND THEIR SHEPHERDS}

Teacher's preparation: Have a small quantity of wool in hand, as suggested in the text. Have prepared, also, some bits of wood and stones or spools. Let the pupils make the spindle and whorl, and try spinning a bit of yarn. Copy from encyclopedias, or secure photographs of spinning and weaving tools, and let pupils examine and discuss them. Permit them to make a simple loom from cardboard or thin wood, and start weaving a mat or doll's hammock. Children who do not care for either of these activities may mount pictures of their own choice or make the booklet. The hour should be marked with a certain freedom, but should be so conducted that the teacher may give a fair amount of information and background in preparation for the lesson. In this connection Stories of Shepherd Life, by Elizabeth Lobingier 
(University of Chicago Press), may be found very helpful.

Procedure: Begin with Psalm 23, asking the pupils to find it in their Bibles and read it aloud. This may be followed by the hymn, "The King of Love My Shepherd Is." Ask the pupils to find in their Bibles and read silently the story of the lost sheep (Luke I5. I-8). Then call upon one of the group to tell the story in his own words.

Begin the more formal part of the lesson by asking the pupils to imagine how man came to tame sheep and make them his own possession. Pupils who have read the chapter may be ready to live the process of domesticating sheep over again in imagination. The leader should be familiar with John Muir's description of wild wool and with other descriptions of the Rocky Mountain sheep, to supplement the text material. Trace the development and change that sheep underwent as they became tame, and lead up to their need of care from men, as this must give the background of the teaching of the love and tenderness of the Good Shepherd, as described in John IO. I2-I5 and Luke I5. I-8. Do not stress too heavily the sacrificial system, as this approach to Jesus is less simple and understandable to children of this age than that of a loving and watchful shepherd who knows their every need. The lesson story may be read aloud by the pupils. Close the lesson hour with a few minutes spent in learning the title verse, the memory verse, or the poem. These may then be used in the worship period. The shepherd hymns, "There's Not a Bird With Lonely Nest," or "How Strong and Sweet My Father's Care!" will be appro- 
priate to sing. Let pupils suggest the content of the closing prayer, and participate in it.

Activity: The teacher should be able to direct the pupils in carrying out the tasks assigned in Numbers 1, 2, and 3 under "Something to Do." Numbers 4 and 5 may be done at home if the pupils are encouraged to do so.

\section{References:}

Stories of Shepherd Life, by Elizabeth Lobingier. National Geographic Magazine, November, I9I6. 


\section{PART V}

\section{THE EARTH AND ITS NEIGHBORS}

WHILE the lessons in this section may be used at any time in the course, it is suggested that winter is a good season at which to take them both because at that time other topics, such as the plant studies and the insect life studies, are not so available, and because clouds and stars are usually more readily seen in winter.

The purpose of the lessons is to direct the child's attention to the wonder and glory of the sky; to help him to a deeper appreciation of God's power and majesty shown through his creation of the heavenly splendors; to help him to gain an idea of the vastness of God's world; to give him a glimpse of the processes through which the world passed in its development, and at the same time to lead him back always to the thought of "in the beginning God."

\section{LESSON XXVIII}

\section{SKYLAND AND CLOUDLAND}

Procedure: Begin by saying that we are leaving the near-at-hand neighbors now to learn something of other friends and helpers that are much farther away, but that are as truly God's creation and God's workers as any that we have studied. Pupils who have read the lesson story before coming to class 
know the names of certain of these helpers, but all pupils will enjoy hearing the beautiful words with which a writer who lived many years ago described them. Read then from Psalm 104. I-4, or Job 37 . 9-I3, I5-I8, 2I-24. "The Heavens Declare Thy Glory" will prove a fitting hymn.

Introduce at this time a prayer as follows:

We will give thanks unto thee, our heavenly Father, and tell of thy marvelous works. For the heavens are thine, the earth also is thine, the world and all that is in it, for thou hast made them, and all the earth shall worship thee, and sing praise to thy name. Amen.

Begin the lesson period by letting the children go to windows, or out of doors for a minute and look up at the sky, then come back ready to describe what each has seen. Do not let them tell at once, but begin to tell them what Ruth and Don saw in the sky when they were in camp. As you describe each type of cloud, show the picture of that form, or uncover it on the board, where it may have been drawn previously in readiness for the lesson. Let each pupil indicate, when the right point is reached, the type of cloud he saw when he looked. If the day chances to be cloudless, tell them the sky looks blue because of the dust helper, and challenge them to see how many. cloud forms they can discover before the next session. Many of the pupils will be able to make very fair drawings of the cloud forms from the photos or blackboard drawings, and these may carry out Ruth's plan of writing Bible verses about clouds under them, and adding them to note or class book.

Talk over the assignments found in "Something 
to Do," and let each pupil take the one that has most interest for him. Plan a simple program of memory work, poems, and display of notebooks, to which friends and parents may be asked at the close of the course, and start pupils to learning the wind poems for that occasion.

Activity: Urge the pupils to find time at home to carry out the tasks assigned in Numbers $I$ and 3. Ask them also to read the lesson story for Lesson XXIX, and to be thinking about the suggestions for activity under "Something to Do."

References: For Lessons XXVIII and XXIX. Starland, by Robert $\mathrm{H}$. Ball.

Astronomy From a Dipper, by E. C. Clarke. National Geographic Magazine, August, I9I9.

\section{LESSON XXIX}

\section{NEIGHBORS IN THE SKY}

Procedure: Begin the class session with a worship period, using first of all the verses found in Psalm I9. I-6, which the pupils may be asked to find and read aloud in unison. Then sing the hymn, "Day Is Dying in the West," noting especially the second stanza and the refrain. At this point the beautiful creation poem found in Genesis I. I-8 may be read by the teacher, to be followed by the hymn, "The Heavens Declare Thy Glory."

If possible, a trip to an observatory, a museum, or a laboratory where there is the apparatus for showing the relative sizes and positions of the sun and planets should be made. If this is not possible, 
the leader may work out a chart giving the facts, though it will not be easy to show even the more important ones in much detail.

In the classroom, talk first of the stars, and study a chart of the sky for the season in which the lesson is being studied. It may be possible to arrange for an evening session of the class when the heavens themselves will form the textbook. If not, let the pupils make a simple chart for individual use, and then urge them to check on it the stars they actually locate and learn to know by name. Make the first charts very simple, and do not try to include those constellations that are sure to puzzle the boy or girl. Begin with the "Dipper," show how to locate the north star, and tell the class where to look for the morning or the evening "star" and its name. This will lead to a discussion of the distinction between planets and stars. Let the lesson lead back to the men who for many years before astronomy had become a science made the heavens their reverent study and who saw the hand of God there. Chaldean and Hebrew shepherd alike looked to God through the wonders they saw in the sky.

In this connection call upon the pupils to tell in their own words what Don and Ruth discovered about their skyland neighbors. Without becoming too technical help the pupils to understand what is meant by planets, stars, shooting stars, constellations, the solar system, how the stars and planets got their names.

Activity: Numbers 4 and 5 will doubtless prove very interesting to the pupils. Give them the necessary directions for carrying out the tasks involved. Urge them to study carefully the chart found in the text. 


\section{LESSON XXX}

\section{A STORY OF THE ROCKS}

Procedure: Use sand table, blackboard, and pictures from geographical readers or texts on geology to illustrate bowlders, pebbles, sand and silt, clay or mud. If possible, have samples of all these forms in the room. Plan for the carrying out of assignments 5 and 6 previous to the class session if at all possible. The lesson may be read aloud in the session by the pupils, with plenty of time to look at the pictures and gain full understanding of them.

When the lesson story is completed in this way take up assignment $I$. Look over and discuss the collections of assignments 3 and 4 .

Begin the period of worship with Job 39. 4-7, I9, 20 and 25-30, which may first be found and read silently by the pupils. Then call upon individuals to read the three sections respectively aloud. Of course it is not to be expected that juniors will thoroughly understand these words, but they will love the majestic roll of the music in them, and will catch something of their spirit. This is one of the fine opportunities to give pupils that in which their "reach exceeds the grasp," a place where the form is given into which more and more meaning will be poured with the passing of time.

The hym'n, "Day Is Dying in the West," may be sung, emphasizing especially the second stanza and the refrain. At this point ask the pupils to bow their heads silently and repeat softly the refrain, 


\section{"Holy, Holy, Holy, Lord God of Hosts!}

Heaven and earth are full of thee,

Heaven and earth are praising thee,

O Lord most High! Amen!"

At this point Psalm I2I may be read in unison by the pupils. The period may close with the hymn, "The King of Love My Shepherd Is," especially the first and fifth stanzas.

Activity: Ask the pupils to read carefully the lesson story for Lesson XXXI and to study especially the tasks assigned in Numbers $1,2,3$, and 4 under "Something to Do."

References: For Lessons XXX and XXXI.

The Earth and Its Life, by A. Waddington Seers.

\section{LESSON XXXI}

\section{WATER AND ICE}

Procedure: Find, in a text on physiography or geology, a picture of a bowlder in the midst of a fertile plain. Ask the children for an explanation of its presence there. Let the lesson be read next, and use explanatory pictures, easily obtained in magazines and school texts, of glaciers, icebergs, levees, and geysers. Encourage questions, and permit children to offer their own explanations, making sure that errors are corrected and ideas are clarified before passing on to new facts.

Carry out assignments 2 and 3, or 4 . No doubt the children will be eager to contribute other facts 
from their reading, observation, or public-school work.

Either at this point, or before dismissing from the session, ask the pupils to read the final lesson, the review, and to think over the questions asked in it, in order to be ready to answer readily at the next session.

As the pupils are thoroughly aroused to the vastness and wonder of God's work lead them into a worship period. Secure a pianist to render some selections from Haydn's "Creation" (Number 7) and then proceed to the use of the following order of worship:

r. Hymn, "This Is My Father's World."

2. Reading, "The One Thousandth Psalm," by Everett Hale.

3. Hymn, "For the Beauty of the Earth."

4. Selected Bible readings by pupils:
(I) Psalm r9. I-6.
(2) Genesis I. I; I. 3 I.
(3) Luke I2. 22-28.

5. Hymn, "We Thank Thee, O Our Father."

6. Prayer: We thank thee, our Father, for our beautiful world, for thy loving care, for beauty, for friends. We pray that thou wilt help us to discover ways in which we may help thee in keeping this world of ours beautiful and happy. Amen.

\section{LESSON XXXII}

\section{COUNTING UP-A REVIEW}

Procedure: It is suggested that the last lesson of the course may well be devoted to a review cover- 
ing the main sections of the course. One method of review described here may be found valuable.

Write on the blackboard the names of the five sections of the course, as follows:

Part I-Back-Yard Neighbors.

Part II-Feathered Friends.

Part III-Garden Life.

Part IV-Four-Footed Comrades.

Part V-The Earth and Its Neighbors.

All these creatures of God's wonder world have been called "neighbors." Why? What do they do for us that they should be called our neighbors? By way of review call upon five different individuals to tell briefly in their own words what these five groups of neighbors really do for us to warrant our calling them neighbors. It is suggested that each report include a brief listing of the numbers of the group being reported upon, and a clear statement of what these neighbors do to help us.

Other members of the group may be asked to supplement the five reports given by other facts. Try to make the class period as vital and interesting as possible, and let it culminate in a wellplanned worship service, emphasizing Number 3 under "Something to Do."

It will be well to have the rooms decorated with pictures illustrating the life and work of neighbors in God's wonder world. Stereopticon pictures at the close of the session, if available, will be highly valuable-pictures of birds, flowers, clouds, animals, and their activities.

Proceed with questions as suggested in the text, or similar ones, as these may be indicated by individual situations. Help pupils to think of their 
part in God's Wonderful World, and aid them in discovering ways in which they may not only make verbal expressions of gratitude, but ways in which they may actually help in keeping God's world happy and comfortable.

This conclusion to the lesson proper will lead naturally into a worship service consisting of the following:

I. "Waltz of the Flowers," by Tschaikowski, played on the piano.

2. Hymn, "Day Is Dying in the West," especially the second stanza and refrain.

3. Repetition of favorite memory verses by individual pupils.

4. Hymn, "The World Is Glad, the World Is Bright."

5. Opportunity for each member of the class to express in a single sentence or two some religious lesson that he has learned from these lessons about his out-of-doors neighbors.

6. Prayer: $O$ God, our Father, we thank thee for our neighbors in the great out-of-doors, for the little insects in our backyards, for the birds whose beauty and cheer gladden our hearts, for the beauties of flowers, for the majesty of the trees, for the friendliness of pets, for the vastness of the heavens, for everything that thou hast provided here for our comfort and happiness. Help us to remember that thou art the Maker of it all and may we be glad to help thee in thy work of making this a brighter and a better world. Amen.

7. Hymn, "This Is My Father's World." 


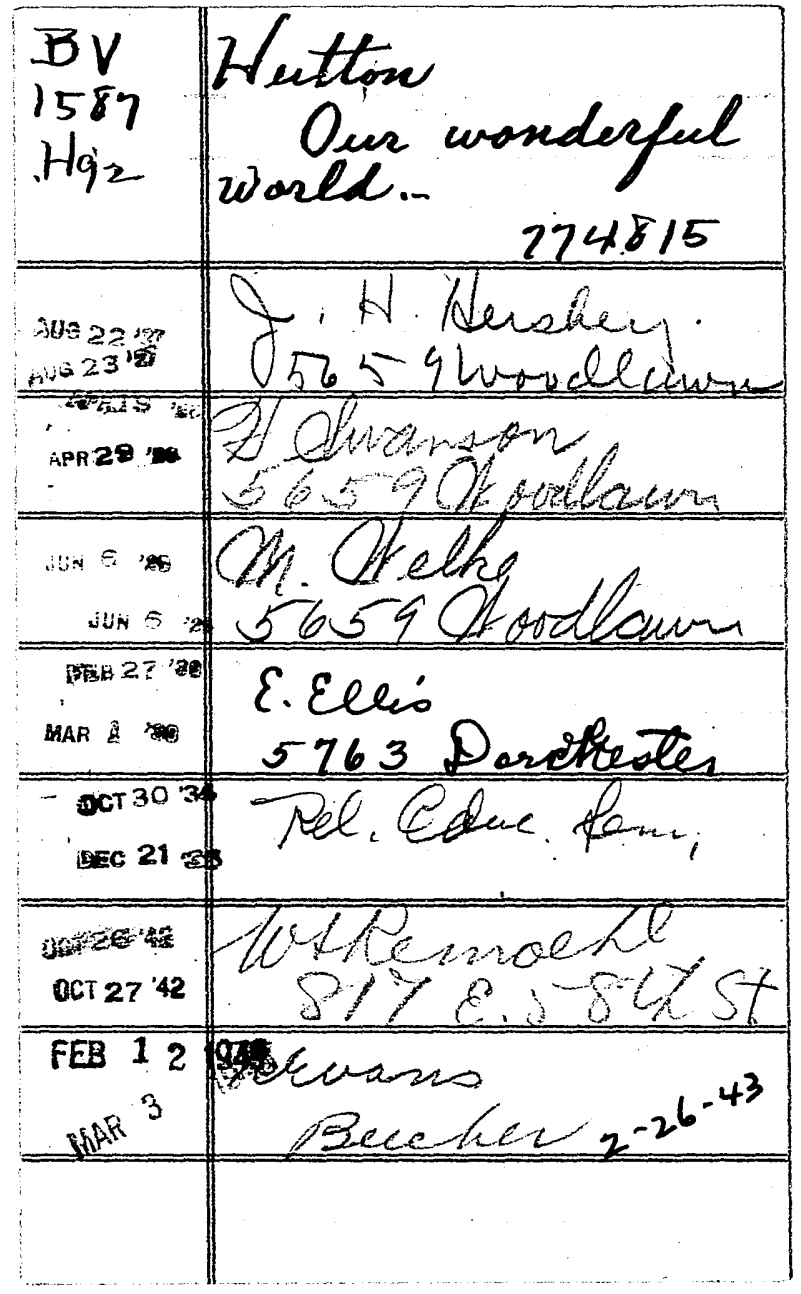




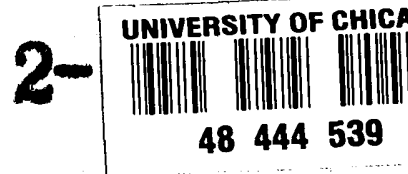

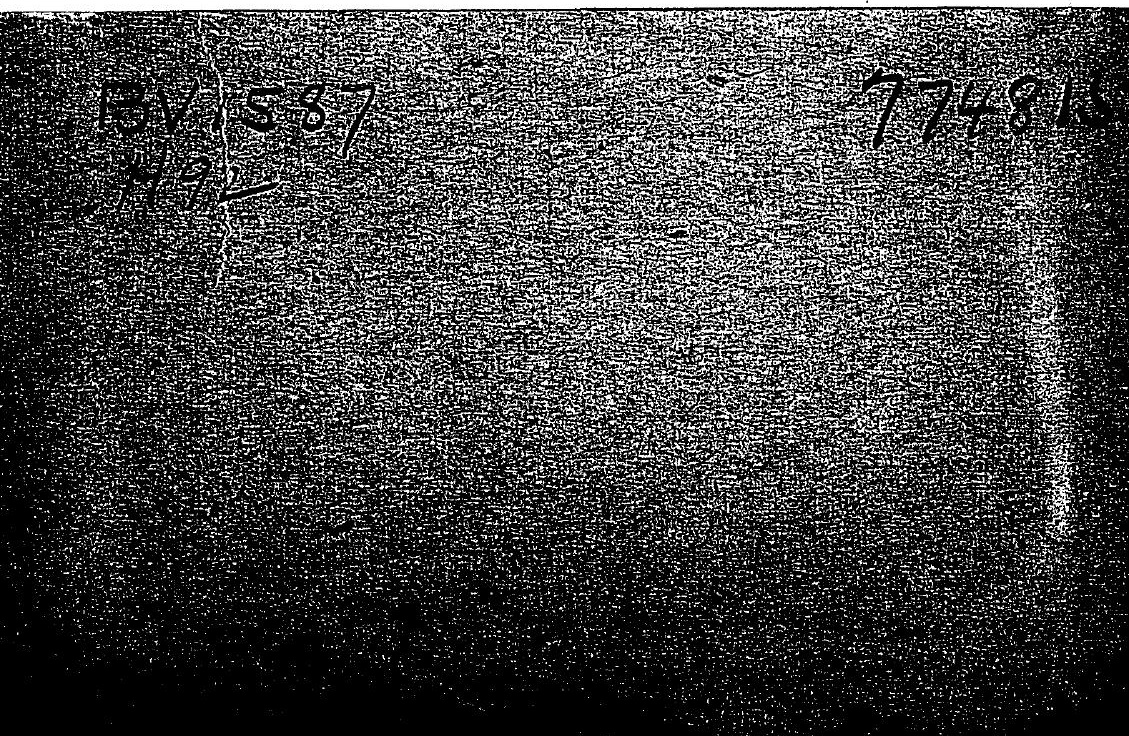




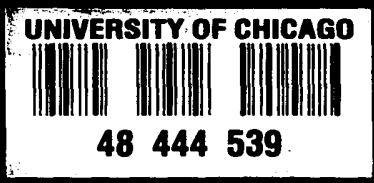

